\title{
An Experimental Investigation of the Cooling System for a Free Piston Stirling Engine
}

Akshay Milind Gupte

West Virginia University, amg0007@mix.wvu.edu

Follow this and additional works at: https://researchrepository.wvu.edu/etd

Part of the Heat Transfer, Combustion Commons

\section{Recommended Citation}

Gupte, Akshay Milind, "An Experimental Investigation of the Cooling System for a Free Piston Stirling Engine" (2018). Graduate Theses, Dissertations, and Problem Reports. 3706.

https://researchrepository.wvu.edu/etd/3706

This Thesis is protected by copyright and/or related rights. It has been brought to you by the The Research Repository @ WVU with permission from the rights-holder(s). You are free to use this Thesis in any way that is permitted by the copyright and related rights legislation that applies to your use. For other uses you must obtain permission from the rights-holder(s) directly, unless additional rights are indicated by a Creative Commons license in the record and/ or on the work itself. This Thesis has been accepted for inclusion in WVU Graduate Theses, Dissertations, and Problem Reports collection by an authorized administrator of The Research Repository @ WVU. For more information, please contact researchrepository@mail.wvu.edu. 


\title{
An Experimental Investigation of the Cooling System for a Free Piston Stirling Engine
}

\author{
Akshay Gupte \\ Thesis submitted to the \\ Benjamin M. Staler College of Engineering and Mineral Resources at West Virginia \\ University \\ in partial fulfilment of the requirements for the degree of \\ Master of Science \\ in \\ Mechanical Engineering \\ Hailin Li, Ph. D., Chair \\ Songgang Qiu, Ph. D., Co-advisor \\ Cosmin Dumitrescu, Ph.D. \\ Vyacheslav Akkerman, Ph.D. \\ Department of Mechanical and Aerospace Engineering \\ Morgantown, West Virginia \\ 2018 \\ Keywords: Free Piston Stirling Engine, Cooling System, Heat Transfer, Reynolds Number, \\ Nusselt Number, Prandtl Number, \\ Copyright 2018 Akshay Gupte
}




\section{Abstract \\ An Experimental Investigation of the Cooling system for a Free Piston Stirling Engine Akshay Gupte}

Free-Piston Stirling Engine (FPSE) has been identified as a good candidate for combined heat and power application (CHP). FPSE being highly efficient and environmentally friendly promises to facilitate the increasing demand in waste heat energy recovery systems. FPSE system consists of three important components: (1) hot side heat exchanger; (2) regenerator; and (3) cold side heat exchanger. The cold side heat exchanger is a crucial part as it enables to maintain an optimal temperature of the working fluid by rejecting heat.

This research contributes to the design of heat exchanger test rig and experimental measurement of cooling heat exchanger. The pressure loss and heat transfer rate are theoretically calculated to design and develop the cooling system. A portable test rig is designed in Solidworks and fabricated to accommodate the components of cooling system. The test rig is used to experimentally investigate the performance of a cross-flow heat exchanger. The experimental data measured is processed to characterize the performance of heat exchanger and to derive a series of parameters and dimensionless number such as Reynolds, Prandtl, and Nusselt number. The experimental study found out that a higher air flow rate is required to necessitate the required heat dissipation rate at lower temperatures. The effect of mass flow rate on heat transfer rate and heat transfer coefficient at three different temperatures indicate that the selected heat exchanger works better at higher temperature. Furthermore, empirical equations calculating the Nusselt Number as a function of Reynolds and Prandtl Number for the liquid and air-side of the cross-flow heat exchanger were derived. 


\section{Dedication}

This thesis work is dedicated to my late grandmother Mrs. Usha Gupte, my parents Mr. Milind

Gupte, Mrs. Sunetra Gupte, my Guru Shri Swami Samarth and Ms. Rupal Jain who has always been by my side and encouraged me to be successful in academics. 


\section{Acknowledgements}

Firstly, I want to express my gratitude towards my committee chair Professor Hailin Li, for mentoring me to complete my course work. He has contributed immensely not only for my thesis but also for my overall academia development. I am thankful to Dr. Li for his guidance and support to present my ideas, review my progress and suggest corrective measures at every stage of my research. I thank him for supporting and motivating me during my illness which indeed helped me to complete my thesis.

Secondly, I want to thank my research co-advisor/project advisor, Professor Songgang Qiu, for allowing me to work for him and letting me contribute for his project. Working in his all new Stirling Engine Lab with all facility, has brought in a positive energy which helped me overcome the challenges I faced during my research. I sincerely thank him for funding me as a student worker. His patience, continuous encouragement, working style, and constant support helped me completing my project and thesis in timely manner. Dr. Qiu is a true inspiration, his constant desire and optimism towards cleaner technologies raises my hopes for a better environment.

Apart from them, I would like to thank my committee members Dr. Cosmin Dumitrescu and Dr. Vyacheslav Akkerman for being extremely patient and understanding my concerns. Their immense knowledge and insightful comments proved to be very vital for the thesis completion. My sincere thanks go to Kelsey Crawford for letting me use the Aero Lab and then the Fluid Dynamics Lab to test the Heat Exchanger. Heartfelt thanks to all the staff in Mechanical and Aerospace Engineering (MAE) Department at West Virginia University (WVU) for assisting me during my time at WVU.

I also want to extend my gratitude to Stirling engine lab mates and research assistant students, Koji Yanaga, Pavan Yadav and Yuan Gao for their backing. A special mention to my Morgantown Friends, Amoolya Lalsare, Rasik Pondicherry, Parikshit Sarda, Kalrav Singh Tomer, Shivangi Yadav and Rahul Koora who spent lot of time, discussing concepts and new ideas related to Heat Transfer. Finally, I thank my family and friends, my parents Milind Gupte and Sunetra Gupte, who have been extremely supportive throughout my life. Their unconditional love and encouragement have always strengthened me. My cousin Akhil Panchal and friends back in India especially Rupal Jain, Onkar Tapkir, Akshay Patil and Darshak Bhuptani for always inspiring and encouraging me to work hard in research area. 


\section{Content}

Chapter 1 Introduction

1.1 Distributed Generation 1

1.2 Working Principle of Free Piston Stirling Engine 2

1.3 Air Cooled and Liquid-Cooled Heat Rejection System 4

1.4 Objectives of the Thesis 4

$\begin{array}{ll}\text { Chapter } 2 \text { Literature Review } & 6\end{array}$

2.1 History of Stirling Engine $\quad 6$

2.2 Thermodynamics Cycle $\quad 6$

Chapter 3 Theory and Methodology 11

3.1 Pressure Loss Calculation 11

3.2 Heat Transfer Calculation $\quad 15$

3.3 Small Liquid to Air Heat Exchanger 17

3.4 Component Selection $\quad 18$

Chapter 4 Experimental Set up $\quad 20$

$\begin{array}{ll}\text { 4.1 Design of Test Rig } & 20\end{array}$

4.2 Testing Equipment and Measuring Instruments 23

4.3 Testing Procedure $\quad 25$

Chapter 5 Results and Discussions 28

5.1 Effect of water flow rate on heat transfer rate at different air flow rate 31

5.2 Effect of water flow rate on heat transfer rate and heat transfer coefficient at different temperatures at constant air flow rate 32

5.3 Effect of Reynolds number and Prandtl number on Nusselt number for water side 34

5.4 Effect of Reynolds number and Prandtl number on Nusselt number for air side at same temperature 36

5.5 Laminar flow correlations for water 37

5.6 Comparison of design requirement and experimental results for heat exchanger $\quad 40$

Chapter 6 Conclusion and Future Work 41

6.1 Conclusion $\quad 41$

6.2 Future Work 42

References

$\begin{array}{ll}\text { Appendix } & 45\end{array}$ 


\section{List of Figures}

Figure 1. Schematic of combined heat and power technology using FPSE. 1

Figure 2. Schematic of FPSE.

Figure 3. PV and TS diagram of FPSE.

$\begin{array}{lr}\text { Figure 4. Ideal stirling cycle PV diagram. } & 6\end{array}$

Figure 5. Flow in a liquid line. 12

Figure 6. Effect of volumetric flow rate on pressure loss. 15

Figure 7. Pump and Hose. $\quad 19$

Figure 8. 2 Rows aluminum honda radiator. 19

Figure 9. Solidworks view of the test rig. $\quad 20$

Figure 10. Front view of the test rig. $\quad 22$

Figure 11. Radiator and fan assembly.

Figure 12. Infrared thermometer.

Figure 13. Thermo-anemometer. 25

Figure 14. Experimental set up in thermo- fluids lab. 27

Figure 15. Schematic of the geometry of tube and fin of the heat exchanger. 29

Figure 16. Effect of water and air flow rate on heat transfer rate (water side). 32

Figure 17. Effect of water flow rate and inlet temperture of water on heat transfer rate at air flow rate of $572.9 \mathrm{cfm}$.

Figure 18. Effect of water flow rate and inlet temperature of water on heat transfer coefficient at air flow rate of 572.9 .

Figure 19. Effect of Reynolds and Prandtl numbers on Nusselt number (water side) at water inlet temperature of $40^{\circ} \mathrm{C}, 50^{\circ} \mathrm{C}$ and $70^{\circ} \mathrm{C}$.

Figure 20. Effect of Reynolds and Prandtl numbers on Nusselt number (water side) at water inlet temperature of $70^{\circ} \mathrm{C}$.

Figure 21. Effect of Reynolds and Prandtl numbers on Nusselt number (water side) at $40^{\circ} \mathrm{C}$, $50^{\circ} \mathrm{C}$ and $70^{\circ} \mathrm{C}$ of water inlet temperature, water flow rate (1 to $6 \mathrm{gpm}$ ) and air flow rate from (682 to 394$)$.

Figure 22. Effect of Reynolds and Prandtl number on Nusselt Number (air side) at inlet water temperature of $70^{\circ} \mathrm{C}$.

Figure 23. Effect of Reynolds Number on Nusselt number at $70^{\circ} \mathrm{C}$. 
Figure 24. Effect of Reynolds Number on Nusselt number at $50^{\circ} \mathrm{C}$.

Figure 25. Effect of Reynolds Number on Nusselt number at $40^{\circ} \mathrm{C}$. 


\section{List of Tables}

Table 1. Results of stirling engine design from sage model. $\quad 7$

Table 2. Thermophysical properties. 13

Table 3. Minor loss coefficient. 14

Table 4. Pressure losses in a liquid line using water/ethylene glycol as a coolant. 14

Table 5. Pressure losses in a liquid line using water as a coolant. 14

Table 6. Properties of air at $30^{\circ} \mathrm{C}$ and $1 \mathrm{~atm} . \quad 16$

Table 7. Initial conditions. 16

Table 8. Calculation of thermal heat capacity. 17

Table 9. Heat exchangers data from AKG global standard cooler. 18

Table 10. Heat exchangers data from Thermal transfer products. 18

Table 11. Component specification 1. 21

Table 12. Component specification 2. 22

Table 13. Omega handheld thermometer. 24

Table 14. Radiator core configurations reference. 30

Table 15. List of cases tested. 31

Table 16. Effect of coolant's (water) flow rate on heat transfer rate (water side) and other parameters at constant air flow rate at $572.9 \mathrm{cfm}$. 31

Table 17. Comparison of design requirement and experimental result at $40{ }^{\circ} \mathrm{C}$. 


\section{List of Nomenclature}

AC - Alternating current

ACS - Air cooling system

cfm - Cubic feet per minute

CHP - Combined heat and power

$\mathrm{CO}_{2}$ - Carbon- dioxide

DC - Direct current

DG- Distributed Generation

ETD - Entering temperature difference

FPSE - Free-piston Stirling engine

gpm - Gallon per minute

IC - Internal Combustion

kW - Kilowatt

lbs - Pounds

LCS - Liquid Cooling System

MAE - Mechanical and Aerospace Engineering

NTU - Number of transfer units

PV - Pressure-Volume

$\mathrm{RG}$ - Remote generation

SE - Stirling Engine

WVU - West Virginia University

$\mathrm{Al}_{2} \mathrm{O}_{3}$ - Aluminum oxide 


\section{List of Symbols}

Acf - Total cross-sectional area of fin

$A_{c t}$ - Total cross-sectional area of tube

$A_{\text {sf }}$ - Total surface area of fin

Ast - Total surface area of tube

$\mathrm{C}_{\mathrm{a}}$ - Heat capacity rate of air

$\mathrm{C}_{\mathrm{p}}$ - Specific heat

$\mathrm{C}_{\mathrm{w}}$ - Heat capacity rate of water

$\mathrm{C}_{\mathrm{a} / \mathrm{w}}$ - Capacity ratio (for air and water)

$\mathrm{C}_{\mathrm{a} / \mathrm{weg}}$ - Capacity ratio (for air and water/ethylene glycol)

Dhfin - Hydraulic diameter of fin

Dhtube - Hydraulic diameter of tube

f - Friction factor

g - Acceleration due to gravity

$h_{a}$ - Heat transfer coefficient of air

$h_{w}-$ Heat transfer coefficient of water

$\mathrm{H}_{\mathrm{f}}$ - Major head loss

$\mathrm{H}_{\text {minor }}$ - Minor head loss

ma - Mass flow rate of air

$\mathrm{m}_{\mathrm{w}}$ - Mass flow rate of water

$\mathrm{m}_{\text {weg }}$ - Mass flow rate of water/ethylene glycol

$\mathrm{N}_{\mathrm{u}, \mathrm{a}}$ - Nusselt Number of air

$\mathrm{N}_{\mathrm{u}, \mathrm{w}}$ - Nusselt Number of water 
$\mathrm{P}_{\mathrm{r}, \mathrm{a}}$ - Prandtl Number of air

$P_{r, w}$ - Prandtl Number of water

$\mathrm{Q}_{\mathrm{a}}$ - Heat capacity rate (air side)

$\mathrm{Q}_{\mathrm{e}}$ - Heat absorbed

Qmax - Maximum heat transfer rate

$\mathrm{Q}_{\mathrm{r}}$ - Heat rejected

$\mathrm{Q}_{\mathrm{w}}$ - Heat transfer rate (water side)

$\mathrm{R}_{\mathrm{e}, \mathrm{a}}$ - Reynolds Number of air

$R_{e, w}$ - Reynolds Number of water

$\mathrm{T}_{\text {in }}$ - Inlet temperature of water

Tout - Outlet temperature of water

$\mathrm{T}_{\mathrm{w}}$ - Temperature of radiator wall

$V_{w}$ - Volumetric flow rate of water

$\mathrm{U}$ - Overall heat transfer coefficient

$\rho$ - Density

$\tau$ - Shear stress

$\Delta P$ - Pressure drop

$\Delta T$ - Temperature difference 


\section{Chapter 1 Introduction}

\subsection{Distributed Generation}

In the year 2013, the efficiency of electricity generation from centralized U.S. power plants was estimated to be $33 \%$, emitting almost 2 billion tons of carbon-dioxide $\left(\mathrm{CO}_{2}\right)$ [1]. Furthermore, losses during transmission and distribution from electricity generation power plant to customer is reported to be $6 \%$. Distributed generation (DG) in which electricity is generated at the point of consumption is a good alternative to reduce the burden on the centralized electricity generation, [1]. A schematic of DG technology is shown in the Figure 1.

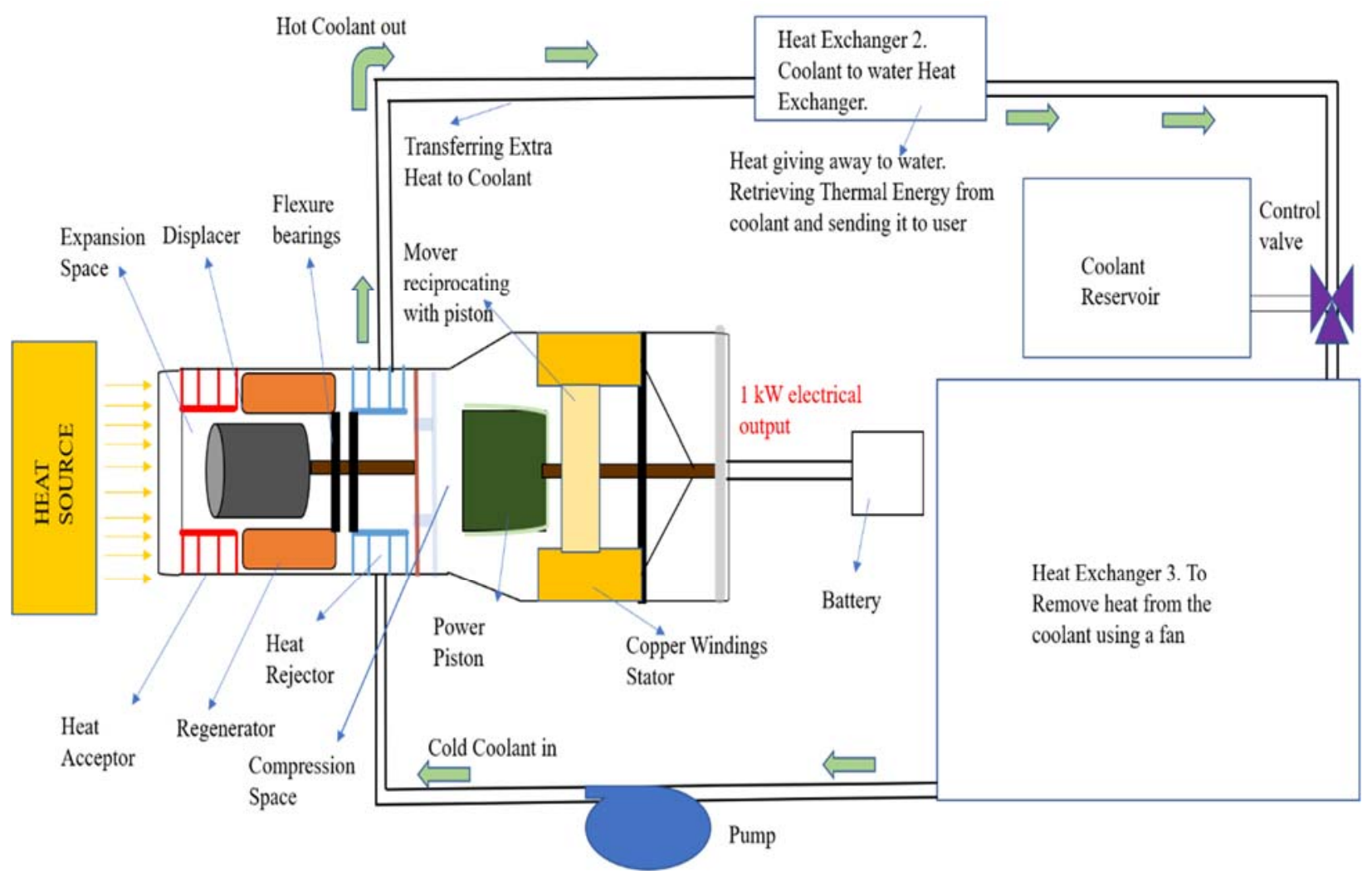

Figure 1. Schematic of Combined heat and power technology using FPSE.

DG usually designed to operate as Combined Heat and Power (CHP) systems produce electricity for home while utilizing the waste heat for space and water heating having high potential energy efficiency. However, these systems are limited by high price and short lifetime. Funded by the GENSETS program, West Virginia University (WVU) teaming with Infinia Corporation, proposed to demonstrate an Advanced Stirling Power Generation system for residential CHP application. 
The project team at WVU is working to develop a $1 \mathrm{~kW}$ Free- Piston Stirling engine (FPSE) that have high fuel to electric efficiency over $30 \%$ [1].

Stirling engine (SE) is a machine that operates on a closed regenerative thermodynamic cycle, involving cyclic compression and expansion of the working fluid at different temperature levels [2]. This differs from an internal combustion (IC) engine, which relies on combustion of combustible air-fuel mixture within the cylinder to push the piston down during the expansion stroke with large amounts of heat rejected in the exhaust gas.

\subsection{Working Principle of Free Piston Stirling Engine}

Stirling Engines have kinematic and free piston arrangement. Kinematic Stirling engines use crankshaft connected to a conventional generator to generate power, though it gives good thermal efficiency, the amplitude of the power-piston and displacer motion is constrained by mechanical linkages [2]. To overcome these difficulties, Free Piston Stirling Engine was conceived, credit to William. T Beale founder of Sunpower Inc. (1974) who first built it in 1960's. With solid engineering and lean method approach, Sunpower perfected the FPSE and made it viable for the world [3]. FPSE does not have a crankshaft, the displacer and power piston of the free piston engine typically move as tuned spring-mass-damper systems in response to pressure and temperature differences [2]. Oscillation of the displacer is encouraged by physical springs or by the compressibility of the working gas. The temperature difference across the displacer maintains the oscillations. The oscillations of power piston windings in the magnetic field generates power [2]. The free-piston Stirling engine contained in a common cylinder is shown in Figure 2. 


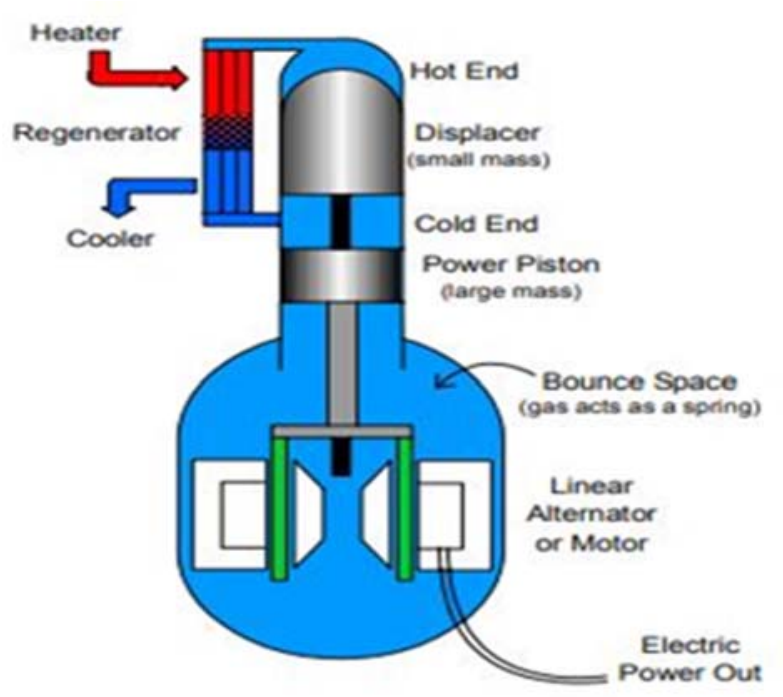

Figure 2. Schematic of FPSE.[2]

The thermodynamic cycle of a Free piston Stirling engine is illustrated below in Figure 3.
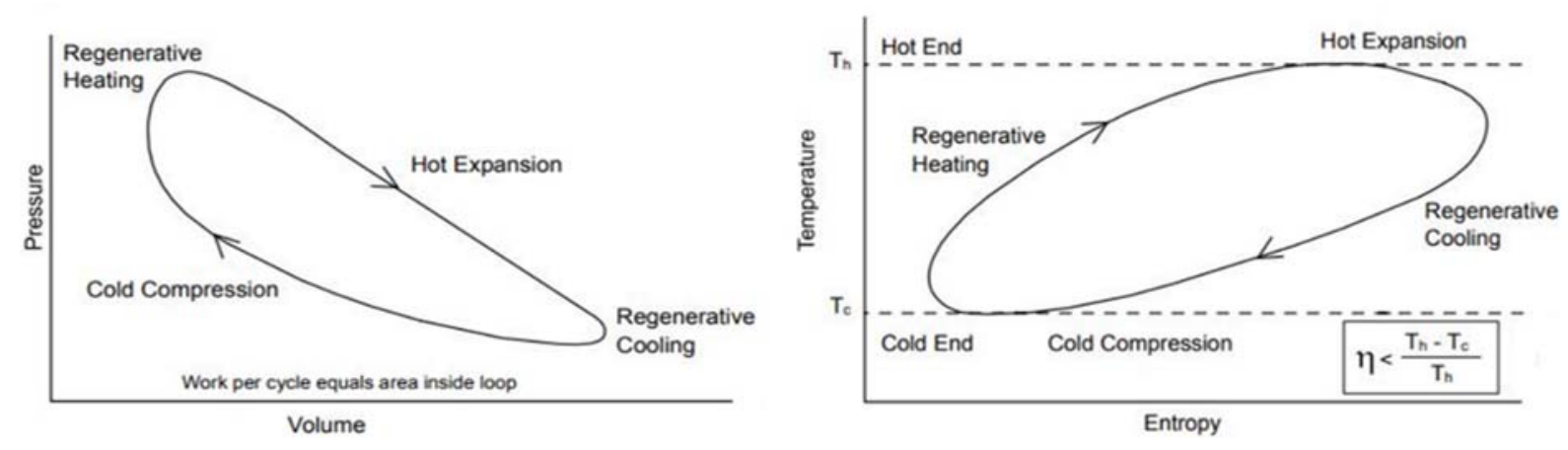

Figure 3. PV and TS diagram of FPSE.[2]

There are four processes involved in Stirling cycle out of which regenerative cooling process is focused in this thesis which involves engine to be externally cooled to relieve the pressure on the piston so that it returns to its original position and the temperature of the working fluid is maintained to its lowest value to get the maximum thermal efficiency. In theory, this can be accomplished in two ways:

- Air blown over the fins of the cooler.

- Coolant in the form of water or ethylene glycol/water mixture is circulated through water jackets surrounding the cooler of the engine. Coolant is then cooled by an external aircooled heat exchanger like an automotive radiator [2]. 


\subsection{Air Cooled and Liquid-Cooled Heat Rejection System}

The Stirling Engine produce good amount heat, so to keep the working fluid and the interior components of the engine cool, the unused heat needs to be removed. Depending upon the size and type of the engine, cooling system is determined, as they affect the overall performance and efficiency of the engine. Air cooling system (ACS) using forced convection which circulates air to cool the unit and protects engine from overheating. ACS though are limited by specific heat, hence to dissipate large power, a large air mass flow is needed incurring extra cost [4].

The heat transfer coefficient of air is of the order of $25<\mathrm{h}_{\text {air }}<250 \mathrm{~W} / \mathrm{m}^{\wedge} 2 \mathrm{~K}$ which is significantly lower than liquid which is of the order of $100<\mathrm{h}_{\text {liquid }}<20000 \mathrm{~W} / \mathrm{m}^{\wedge} 2 \mathrm{~K}$. Therefore Liquid cooling systems (LCS) offer better cooling at lower flow rates. The liquid cooling system consists of heat exchanger (integral part), storing tank, thermostat and water pump, with the pump distributing the liquid coolant to the engine block through hoses. The heat is transferred to the coolant, which is directed through the heat exchanger (radiator) where air cools it. The disadvantage of the liquidcooling systems is that they are more expensive to produce than air-cooled engines and they require additional design consideration. However, LCS is more durable and powerful than their counterparts [4].

\subsection{Objectives of the Thesis}

The work submitted in the thesis contributes to the $1 \mathrm{~kW}$ FPSE project described in section 1.1, concentrating on removal of heat from the cold side of the engine using a Heat exchanger, to which theoretical and experimental analysis were performed. A liquid cooled system is designed and built for $1 \mathrm{~kW}$ FPSE. To build an optimized system, design parameters are defined, and they are as follows:

- To maintain an optimal operating temperature on the cold side of FPSE at ambient temperature.

- To maximize Stirling engine's thermal efficiency by dissipating required amount of heat to ambient air.

- To procure the necessary components for the cooling system.

- To minimize the overall mass of the cooling system without affecting its performance.

- To minimize the electrical power requirement to run the cooling system. 
The experimental work for this project is initiated by testing the procured heat exchanger at three different temperatures, wherein the flow rates on the air and liquid side are varied. To say it in a nutshell,

- To develop and design a high efficiency, low cost and low power cooling system/heat rejection system to increase the net power output of a $1 \mathrm{~kW}$ Stirling engine.

- To build a test rig to accommodate all the cooling system components such as heat exchanger, pump, tank, hoses, valves and thermocouple.

- To experimentally investigate the performance of Heat exchanger over a wide range of flow rates and temperatures.

- To analyze results to get the required heat rejection at three different coolant inlet temperatures.

- To derive an empirical equation of Nusselt Number as a function of Reynolds and Prandtl Number on the liquid side and air side.

The information presented in each chapter is as follows,

- Chapter 2 mainly focuses on the recent improvements in FPSE and experimental investigations performed on the cold side of the heat exchanger of FPSE. The parametric analysis of various cross-flow heat exchangers is also introduced in this section.

- A detailed explanation on the theory for pressure loss and heat transfer for a cooling system is presented in Chapter 3.

- Chapter 4 presents a summary of the experimental set up, the components used to build a test rig and measuring instruments used for experiments is explained.

- Chapter 5 reports the experimental results for the heat exchanger for different operating conditions. It also compares the theoretical and experimental heat transfer results for the heat exchanger.

- Lastly, a brief conclusion is explained for the thesis and few recommendations are presented in this section to further hone this research. 


\section{Chapter 2 Literature Review}

\subsection{History of Stirling Engine}

Stirling engine invented in 1816 by Scottish Minister Robert Stirling, adored a moderate commercial success before the inception of Diesel and Otto engines[5]. It operates quietly and is adaptable to almost any heat source [5]. The heat input is transferred to the working gas inside the Stirling Engine through a hot heat exchanger (heater) at a high temperature. The heat that is not converted to the work is rejected to the cooling water in the cold heat exchanger (cooler) at $40{ }^{\circ} \mathrm{C}$ to $80^{\circ} \mathrm{C}$ [5]. The Stirling cycle operates as a closed system with the working gas retained in the cylinder. The key advantages of Stirling engine are low noise operation, fuel flexibility, controllable emissions, and high thermodynamic efficiency, suited very well in the distributed generation market as an environmentally green alternative to mature DG technologies [6].

\subsection{Thermodynamics Cycle}

The thermodynamic analysis of actual Stirling cycle is complex due to the transient heat transfer processes involved, thus an idealized model of the Stirling cycle is defined in the following PV diagram[7]

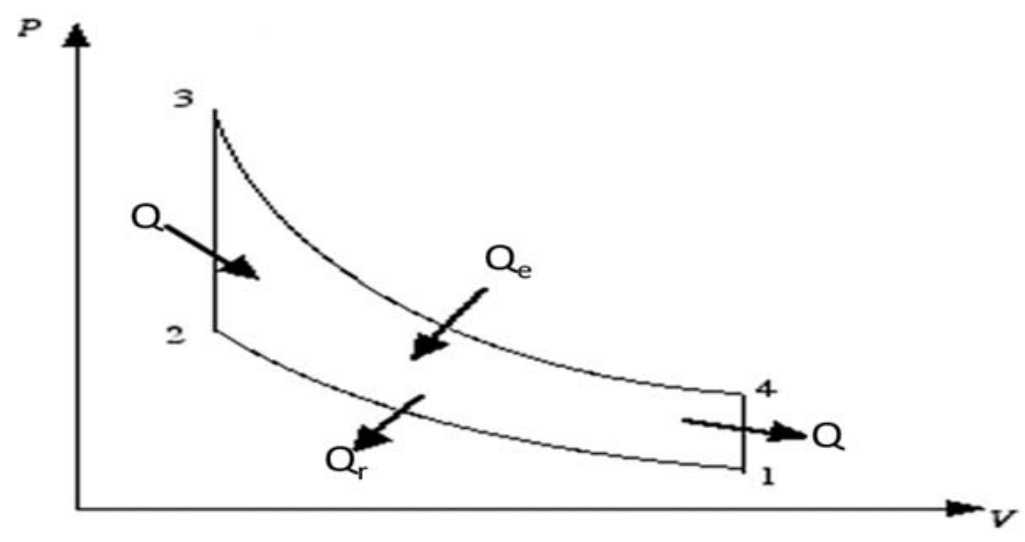

Figure 4. Ideal stirling cycle PV diagram. [7]

Process (1-2) is the isothermal compression process, during which heat $\mathrm{Q}_{\mathrm{r}}$ is rejected to the cooling water. Process (2-3) is the constant volume displacement process during which heat Q is absorbed from the regenerator matrix. Process (3-4) is the isothermal expansion process producing power, during which heat $Q_{e}$ is absorbed from the external heat source, and finally process (4-1) is the constant volume displacement process during which heat $\mathrm{Q}$ is stored in the regenerator matrix[7]. The ideal Stirling cycle consists of four distinct processes, amongst these processes, the isothermal compression process is described in detail [6]. 


$$
\begin{aligned}
& \mathrm{P}_{2}=\frac{P_{1} V_{1}}{V_{2}} \\
& T_{1}=T_{2}=T_{\text {min }}
\end{aligned}
$$

Heat Rejected $Q_{r}=$ Work done $W$

$$
Q_{r}=W=P_{1} V_{1} \times \ln \left(\frac{V_{2}}{V_{1}}\right)=m \times R \times T_{1} \times \ln \left(\frac{V_{2}}{V_{1}}\right)
$$

Similar to the isothermal compression process, $\mathrm{Q}_{\mathrm{e}}$ in isothermal expansion process is quantified as follows[6]:

$$
Q_{e}=W=P_{3} V_{3} \times \ln \left(\frac{V_{4}}{V_{3}}\right)=m \times R \times T_{3} \times \ln \left(\frac{V_{4}}{V_{3}}\right)
$$

The main components of the FPSE are hot heat exchanger, regenerator, cold heat exchanger, power piston and displacer. Components having maximum effect on the performance and cost of the Stirling engine are the heat exchangers. The cold heat exchanger is required to dissipate heat by forced convection from the working gas to external heat rejector so that the temperature of the working gas and cylinder walls remains at the lowest possible value. Therefore, a high capacity external heat exchanger needs to be developed and analyzed to increase engine's thermal efficiency.

One-dimensional thermodynamic modelling tool, known as Sage software is used to optimize Stirling cycle engines and to predict Stirling engine performance. Predictions for Free piston Stirling engine design from Sage Model is presented below, [8]

Table 1. Results of stirling engine design from sage model.

\begin{tabular}{|l|l|}
\hline Data & Value \\
\hline Electrical Power output (W) & 1215 \\
\hline Total thermal input (W) & 3017 \\
\hline Heat rejected (W) & 1493 \\
\hline Net cycle power (W) & 1350 \\
\hline Stirling cycle efficiency (\%) & 44.74 \\
\hline
\end{tabular}


The predicted heat rejected from Sage model is 1493 W. Based on this, a cooling system is devised, to reject $2 \mathrm{~kW}$. Heat dissipation rate of $2 \mathrm{~kW}$ is chosen to have necessary safety margin. Each component of the cooling system is examined to ensure that they meet their operational life.

Project at WVU on Advanced Stirling engine endeavor to carefully manage heat inside the cylinder using additive manufacturing to construct one layer at a time. Building one piece minimizes interfacial heat losses and improves heat transfer leading to increased efficiency[9]. Moreover, flexure-supported piston and displacers in FPSE eliminate the primary failure mechanisms to the vast majority[9]. The $1 \mathrm{~kW}$ FPSE developed by Infinia corporation for European market, grid connected, combined heating and power cogeneration applications has achieved more than 8,400 hours of maintenance-free operation. The Remote Generation (RG-1000) machine for European application operates with $13.8 \mathrm{~W} / \mathrm{kg}$ with a potential to improve power density by 40 to $50 \%$ [10].

Cold end temperature in FPSE is of critical importance, normally it ranges from $40^{\circ} \mathrm{C}$ to $80^{\circ} \mathrm{C}$ Increasing the cold end temperature of the Stirling engine increases the linear alternator temperature reducing the alternator efficiency by $5 \%$ combined with decrease in Carnot efficiency[10]. Hence, special attention is provided to maintain an operating temperature in cold heat exchanger.

Sowale and Kolios [11] presented a numerical investigation on the quasi-steady state model of gamma type free piston Stirling engine. He observed working gas temperature of $541.3^{\circ} \mathrm{C}$ in the heater and $49.8^{\circ} \mathrm{C}$ in the cooler which resulted in $996.7 \mathrm{~W}$ of power. His work described the thermodynamic analysis of the engine's heat exchangers, observing changes in the cold side temperature in the range of $55^{\circ} \mathrm{C}$ to $90^{\circ} \mathrm{C}$. At a fixed heater temperature, increase in cooler temperature decreased the power output of the engine. The thermal efficiency also reduces from $22.4 \%$ to $8.11 \%$. The increased cooler temperature leads to reduction in pressure of the working gas, affecting the net work done. Asnaghi et. al also observed similar results for his numerical model. The Reynolds number and the flow pattern of the working gas was also affected as they changed gradually from turbulent to laminar in the cold end from 6792 to 1782 [11]. To further support the findings, this thesis primarily focuses on rejecting heat at three different temperatures in the range similar to that of the cold end temperature in the FPSE, by designing a heat exchanger with an appropriate flow rate of coolant and air, so that an optimal temperature is maintained, and the effects of higher cold end temperature reported by Sowale is evaded. 
The experimental set up in this thesis has been designed similar to the configuration used by Yadav and Singh [12]. The details of the experimental set up used in this thesis is explained in Chapter 3. Yadav and Singh present a parametric study on automotive radiator. A comparative analysis is completed between different coolants such as water and mixture of water and propylene glycol in the ratio of 40:60. The investigation concludes that water increases the effectiveness and cooling capacity of a radiator due to its high specific heat value but has a disadvantage because of its corrosive nature. With an increase in the inlet's coolant temperature, the cooling capacity and effectiveness of the radiator increases. Cooling capacity and effectiveness are also in direct relation with the coolant's mass flow rate [12]. A similar study was performed by Gollin and Bjork [13] to demonstrate the relative performance of coolant mixtures in terms of heat transfer, coolant pressure drop and radiator effectiveness for a range of coolant and air flow rates. The results concluded that the most effective of the coolants in transferring heat in the test radiator is water followed by 50:50 ratio of water and ethylene glycol and then 50:50 ratio of water and propylene glycol. They documented that when air side of the radiator contributes majority of the heat transfer resistance, the effect of changing coolant is negligible [13].

Chen et.al [14] performed an experimental study on the heat transfer characteristics of a tube and fin radiator. Based on the experimental results, regression equations of heat dissipation rate, coolant pressure drop, and air pressure drop were developed. The results show, heat dissipation rate of the radiator grew as the inlet coolant temperature, coolant volume flow rate and cooling air velocity increased. A complete set of numerical parametric study carried out by Oliet et.al [15] revealed similar facts about the overall behavior of an automobile radiator working at usual range of operating conditions. The results suggested that the overall heat transfer coefficient was almost independent of the air inlet temperature and was mostly dependent on the coolant flow regime represented by the Reynolds number.

It is also reported by Nirnjalkumar and Gopal [16] that the addition of $\mathrm{Al}_{2} \mathrm{O}_{3}$ nano particles to the water base significantly improves the heat transfer characteristics in a radiator. Out of the three operating parameters which are the nanofluid concentration, flow rate and inlet temperature, the heat transfer characteristics is mostly dominated by nanofluid concentration. Finally, the theoretical and experimental radiator analysis performed in this thesis is in accordance to the study performed by Carl et.al [17]. This study first performs the theoretical calculation of the convective 
heat transfer coefficient of the internal fluid flow through the radiator's non-circular tubes and external fluid flow across the radiator tubes and fins. The experimental values of heat transfer rate and outlet temperature of liquid are in good agreement with the theoretical analysis but are different for air because of the presence of fins. Fin effectiveness plays a crucial role for higher air side heat transfer rate and higher temperature difference for air. Similar results were obtained in the experimental analysis performed in the thesis. 


\section{Chapter 3 Theory and Methodology}

Following the literature survey, theoretical analysis are performed for designing a liquid cooled heat rejection system. This section presents theory and methods used to calculate pressure loss and heat transfer. Different small-scale heat exchangers and automotive radiators were searched, before procuring a car radiator. Similar analysis was performed to acquire a water pump.

The calculation of pressure drop and heat transfer are essential for the design and development of a cooling system[18]. The pressure drop is a parameter critical to size a pump. Total pressure drop is influenced by static head, frictional losses, flow regime, bents, valves, sudden expansions and contractions. Similarly, the calculation of heat dissipation rate is crucial in sizing a heat exchanger. Temperature range requirement also defines the thermal factor and plays a very important role in choosing the right liquid for the application. In this section, lower ambient temperatures below 20 ${ }^{\circ} \mathrm{C}$ are not taken into consideration wherein water/ethylene glycol mixture in 50:50 ratio works best due to its antifreeze property.

Water is one of the best heat transfer fluids used as coolant due to its wide availability and high specific heat at different temperature. In FPSE linear alternator application, water as a coolant works fine when outside air temperature is in the limiting range, also the temperature in the cold side of the heat exchanger in FPSE is substantially lower than the limiting boiling point value of water at working pressure. In this research, water is used to experimentally investigate the performance of the heat exchanger. In reality, coolant (water) is passed through the water jackets

in FPSE after which it travels through the tubes of heat exchanger where heat is rejected to the surroundings. Once the temperature of the coolant drops down, it is passed again to the engine to remove heat by using a centrifugal pump.

\subsection{Pressure Loss Calculation}

The main objective in this section is to examine the pressure losses in the liquid flow line for the cooling system [18]. Two categories of flows Laminar and Turbulent are studied and brief explanation on the major and minor losses is presented. In Figure 5, an incompressible fluid flow in a hose is shown which loses its energy due to friction as it interacts with the wall. 


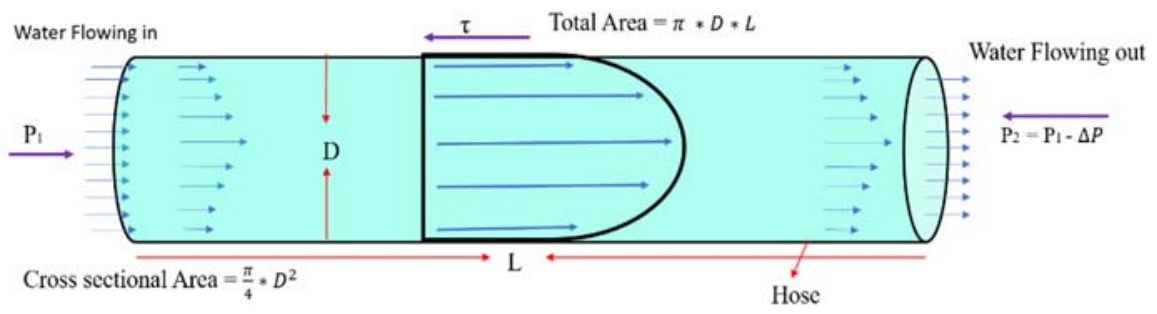

Figure 5. Flow in a liquid line

From Newton's Law, shear stress $\tau=\mu \times \frac{d u}{d y}$, where $\mu$ is the dynamic viscosity is and $\frac{d u}{d y}$ is the variation in velocity in y direction. Applying force balance, total pressure loss is quantified as follows:

$$
(\Delta P)=4 \tau \times\left(\frac{L}{D}\right)
$$

Further, the Pressure drop is divided into two categories

- Major head losses (Frictional Losses) - Due to the wall shear stress in the tube element.

- Minor head losses - Due to the piping components.

Major losses are derived by Darcy- Weisbach equation used for incompressible flow stated as $[18]$,

$$
H_{f}=(f) \times\left(\frac{L}{D}\right) \times\left(\frac{V^{2}}{2 g}\right)
$$

This is Darcy - Weisbach Equation valid for duct flows for both laminar and turbulent conditions. This equation is the best empirical relation for pipe flow resistance calculation. Friction coefficient for laminar flow ( $\operatorname{Re}<<<2000)$, is obtained using Hagen-Poiseuille flow equation defined below,

$$
f=\left(\frac{64}{R e}\right)
$$

For turbulent flow where,

$$
4000<\operatorname{Re}<1 \times 10^{5}
$$

either blasius equation is used for friction factor which is given by,

$$
f=\left(\frac{0.3164}{R e^{0.25}}\right)
$$

or Moody Diagram is used to find friction coefficient over a wide range of roughness.

Minor head losses in a liquid flow line occur due to the presence of valves, elbows, joints etc. A minor loss is expressed in terms of loss coefficient $\mathrm{k}$ as a function of velocity given by, 


$$
H_{\text {minor }}=k \times\left(\frac{V^{2}}{2 g}\right)
$$

A liquid line system contains transitional sections in which the hose diameter might differ from the diameter of a connector, diffuser or valve. Any change in the area accounts for losses which should be considered in the pressure drop calculation. Apart from the entrance and exit losses, analysis is also done on the sudden expansion and sudden contraction losses occurring in the system. The minor loss coefficient for these losses are presented below,

$$
\begin{gathered}
K_{e}=\frac{\left(1-\beta^{2}\right)^{2}}{\beta^{4}} \\
K_{c}=0.5\left(1-\beta^{2}\right) \times \frac{\sqrt{\sin \frac{\theta}{2}}}{\beta^{4}}
\end{gathered}
$$

where $\beta$ accounts for change in diameter of two sections, $\beta=\frac{d 2}{d 1}$ and $\theta \geq 45$

Referring to the pressure losses equations, the pressure drop for a range of water flow rates and hose diameter, while the hose length is 2 meters is calculated. Thermophysical properties of water and water/ethylene glycol is presented in Table 2.

Table 2. Thermophysical properties.[19]

\begin{tabular}{|c|c|c|c|}
\hline \multirow{2}{*}{$\begin{array}{c}\text { Thermophysical Properties } \\
\mathbf{a} \mathbf{4 0}^{\circ} \mathrm{C} \text { to } \mathbf{8 0}{ }^{\circ} \mathrm{C}\end{array}$} & Water & $\begin{array}{c}\text { Water/Ethylene } \\
\text { Glycol }\end{array}$ & \multirow{2}{*}{ Units } \\
\cline { 2 - 4 } Density & 981.9 & 1035.7 & $\frac{\mathrm{kg}}{\mathrm{m}^{3}}$ \\
\hline Thermal Conductivity & 0.65 & 0.45 & $\frac{\mathrm{W}}{\mathrm{m} \times{ }^{\circ} \mathrm{C}}$ \\
\hline Dynamic Viscosity & $0.5 \times \mathrm{E}-3$ & $3.4 \times \mathrm{E}-3$ & $\frac{\mathrm{kg}}{\mathrm{m} \times \mathrm{sec}}$ \\
\hline Kinematic Viscosity & $5.09 \times \mathrm{E}-7$ & $3.32 \times \mathrm{E}-6$ & $\frac{\mathrm{m}^{2} / \mathrm{sec}}{\mathrm{J}}$ \\
\hline Specific Heat & 4188 & 3376 & $\frac{\mathrm{kg} \times{ }^{\circ} \mathrm{C}}{}$ \\
\hline Prandtl Number & 3.2 & 28.6 & \\
\hline
\end{tabular}

Total pressure losses calculated from excel code are reported in appendix, whereas Table 4 and Table 5 demonstrate losses for a particular flow rate for a mixture of water and ethylene glycol in 
50:50 ratio and for pure water respectively. Minor Losses are also quantified for bends, fittings, valves, sudden expansion and contraction tabulated below,

Table 3. Minor loss coefficient.[20]

\begin{tabular}{|c|c|}
\hline Conditions & Kl \\
\hline $180^{\circ}$ bend & 1.5 \\
\hline Fittings & 1 \\
\hline 2 valves & 4.6 \\
\hline Sudden expansion & 3.3 \\
\hline Sudden contraction & 2.05 \\
\hline TOTAL & 12.5 \\
\hline
\end{tabular}

Table 4. Pressure losses in a liquid line using water/ethylene glycol as a coolant.

\begin{tabular}{|l|l|l|l|l|}
\hline \multirow{2}{*}{\multicolumn{1}{c|}{ Calculated Data }} & \multicolumn{4}{c|}{ Hose Diameter, m } \\
\cline { 2 - 6 } & & & & \\
& 0.012 & 0.015 & 0.019 & 0.025 \\
\hline Volumetric flow rate (gpm) & 2 & 2 & 2 & 2 \\
\hline Major head loss (meter) & 0.43 & 0.15 & 0.05 & 0.01 \\
\hline Minor head loss (meter) & 0.78 & 0.32 & 0.12 & 0.04 \\
\hline Total pressure drop (pascal) & 12389.43 & 4823.93 & 1787.05 & 568.37 \\
\hline
\end{tabular}

Table 5. Pressure losses in a liquid line using water as a coolant.

\begin{tabular}{|l|l|l|l|l|}
\hline \multirow{2}{*}{ Calculated Data } & \multicolumn{4}{c|}{ Hose Diameter, m } \\
\cline { 2 - 5 } & \multirow{2}{*}{0.012} & 0.015 & 0.019 & 0.025 \\
\hline Volumetric flow rate (gpm) & 2 & 2 & 2 & 2 \\
\hline Major head loss (meter) & 0.25 & 0.09 & 0.03 & 0.008 \\
\hline Minor head loss (meter) & 0.78 & 0.32 & 0.12 & 0.04 \\
\hline Total pressure drop (pascal) & 10011.34 & 3945.64 & 1479.52 & 476.72 \\
\hline
\end{tabular}


Comparison of pressure losses for two different mixture for same hose diameter but for different range of flow rates is shown in Figure 6.

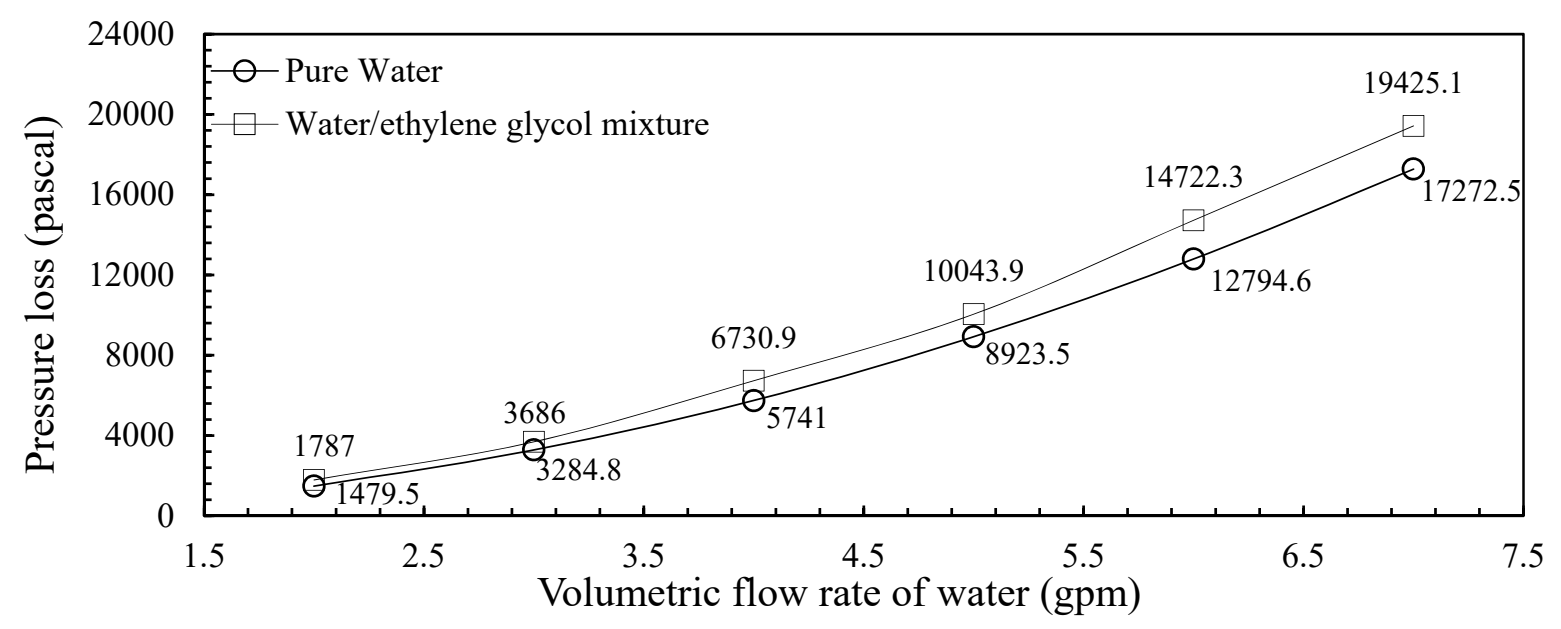

Figure 6. Effect of volumetric flow rate on pressure loss.

\subsection{Heat Transfer Calculation}

Heat transfer rate by convection follows Newton's Law of Cooling which is given by,

$$
Q=h \times A \times\left(T_{s}-T_{\infty}\right)
$$

where $T_{S}$ depends on constant heat flux or constant temperature boundary conditions and $\mathrm{h}$ is the average heat transfer coefficient. To get the required heat removed, energy balance equation plays a vital role which is as follows:

$$
Q=m \times C_{p} \times \Delta T
$$

where $\mathrm{m}$ is the mass flow rate, $\mathrm{C}_{\mathrm{p}}$ is specific heat capacity and $\Delta T$ is temperature difference of inlet and exiting fluid.

Cross flow heat exchangers due to its simple design and having characteristics similar to counterflow are widely used in liquid cooling system. Fan flow rate of $500 \mathrm{cfm}$ and ambient temperature of $30{ }^{\circ} \mathrm{C}$ is considered for analysis. Thermophysical properties of air is presented in Table 6. 
Table 6. Properties of air at $30^{\circ} \mathrm{C}$ and $1 \mathrm{~atm}$.

\begin{tabular}{|l|l|l|}
\hline Properties of Air & Value & Units \\
\hline Density & 1.15 & $\mathrm{~kg} / \mathrm{m}^{3}$ \\
\hline Specific Heat Capacity $\mathrm{C}_{\mathrm{p}}$ & 1005.5 & $\mathrm{~J} / \mathrm{kg} \times{ }^{\circ} \mathrm{C}$ \\
\hline Dynamic Viscosity u & $1.88 \mathrm{E}-05$ & $\mathrm{~kg} / \mathrm{m} \times \mathrm{sec}$ \\
\hline Kinematic Viscosity v & $1.63 \mathrm{E}-05$ & $\mathrm{~m}^{2} / \mathrm{sec}$ \\
\hline Thermal Conductivity k & 0.03 & $\mathrm{~W} / \mathrm{m} \times{ }^{\circ} \mathrm{C}$ \\
\hline Prandtl Number & 0.71 & \\
\hline
\end{tabular}

Heat dissipation rate of $2 \mathrm{~kW}$ is considered to compensate for any heat losses incurring in the heat rejection unit, as no system is $100 \%$ efficient. Further analysis is performed using NTU Effectiveness Method [21]. Summary of the initial conditions used for heat exchanger design are presented in the Table 7.

Table 7. Initial conditions.

\begin{tabular}{|c|c|}
\hline Parameters & Estimated Values \\
\hline Heat transfer rate & 2000 Watts $(\mathrm{W})$ \\
\hline Mass flow rate of water $\mathrm{m}_{\mathrm{w}}$ & $0.24 \mathrm{~kg} / \mathrm{sec}(4 \mathrm{gpm})$ \\
\hline Mass flow rate of water/ ethylene glycol $\mathrm{m}_{\mathrm{weg}}$ & $0.26 \mathrm{~kg} / \mathrm{sec}(4 \mathrm{gpm})$ \\
\hline Temperature at inlet for both the fluids & $40^{\circ} \mathrm{C}$ \\
\hline Ambient temperature & $30^{\circ} \mathrm{C}$ \\
\hline Mass flow rate of air $\mathrm{m}_{\mathrm{a}}$ & $0.28 \mathrm{~kg} / \mathrm{sec}(500 \mathrm{cfm})$ \\
\hline Entering temperature difference (ETD) & $10^{\circ} \mathrm{C}$ \\
\hline
\end{tabular}


The theoretical results using the NTU- effectiveness method is mentioned in the Table 8 .

Table 8. Calculation of thermal heat capacity.

\begin{tabular}{|c|c|}
\hline Parameters & Value \\
\hline Water heat capacity rate $\mathrm{C}_{\mathrm{w}}\left(\mathrm{W} /{ }^{\circ} \mathrm{C}\right)$ & 1002.96 \\
\hline Water/Ethylene glycol heat capacity rate $\mathrm{C}_{\text {weg }}\left(\mathrm{W} /{ }^{\circ} \mathrm{C}\right)$ & 865.15 \\
\hline Air heat capacity rate $C_{a}=C_{\min }$ & 281.96 \\
\hline Capacity ratio $\mathrm{C}_{\mathrm{a} / \mathrm{w}}$ (for air and water) & 0.28 \\
\hline Capacity ratio $\mathrm{C}_{\mathrm{a} / \mathrm{weg} \text { (for air and water/ethylene glycol) }}$ & 0.33 \\
\hline $\mathrm{Q}_{\max }(\mathrm{kW})$ & 2.82 \\
\hline $\mathrm{Q}(\mathrm{kW})$ & 2 \\
\hline Effectiveness $\varepsilon$ (same for both the fluids) & 0.70 \\
\hline Number of transfer units for water $\left(\mathrm{NTU}_{\mathrm{w}}\right)$ & 1.44 \\
\hline Number of transfer units for water/ethylene glycol mixture (NTU $\left.\mathrm{Neg}_{\text {weg }}\right)$ & 1.49 \\
\hline $\mathrm{U}^{*} \mathrm{~A}$ using water $\left(\mathrm{W} /{ }^{\circ} \mathrm{C}\right)$ (Thermal Capacity) & 406.82 \\
\hline $\mathrm{U}^{*} \mathrm{~A}$ using water/ethylene glycol $\left(\mathrm{W} /{ }^{\circ} \mathrm{C}\right)($ Thermal Capacity) & 420.35 \\
\hline $\begin{array}{l}\text { Overall heat transfer coefficient } \mathrm{U} \text { for the finned tube heat exchanger } \\
\text { (water in the tubes and air as a cross flow) }\left(\mathrm{W} / \mathrm{m}^{2}{ }^{\circ} \mathrm{C} \text { ) }\right.\end{array}$ & $25 \sim 50$ \\
\hline Area estimation for the heat exchanger $\left(m^{2}\right)$ & $8.14<\mathrm{A}<16.27$ \\
\hline
\end{tabular}

\subsection{Small Liquid to Air Heat Exchanger}

Liquid to air heat exchangers from private vendors were searched in this research. Liquid to air heat exchangers from AKG Global standard cooler and Thermal transfer product were taken into consideration but eliminated due to high price. Heat exchanger data collected from these two OEMs is mentioned in Tables 9 and 10 respectively. 
Table 9. Heat exchangers data from AKG global standard cooler.

\begin{tabular}{|c|c|c|c|}
\hline Model & D30 & A15 & A20 \\
\hline Fan Motor & 12 V. DC & $110 \mathrm{~V} . \mathrm{AC}$ & $110 \mathrm{~V} . \mathrm{AC}$ \\
\hline Power & $310 \mathrm{Watts}$ & 368 Watts & 414 Watts \\
\hline Weight & $32 \mathrm{lbs}$ & $57 \mathrm{lbs}$ & $67 \mathrm{lbs}$ \\
\hline Material & Aluminum & Aluminum & Aluminum \\
\hline
\end{tabular}

Table 10. Heat exchangers data from Thermal transfer products.

\begin{tabular}{|c|c|c|c|c|}
\hline Model & MA 32 & MA48 & DH524 & DH 535 \\
\hline Fan Motor & $12 \mathrm{~V} . \mathrm{DC}$ & $12 \mathrm{~V} . \mathrm{DC}$ & Fan not included & Fan not included \\
\hline Power & 266.4 Watts & 266.4 Watts & - & - \\
\hline Weight & $28 \mathrm{lbs}$ & $45 \mathrm{lbs}$ & $27 \mathrm{lbs}$ & $53 \mathrm{lbs}$ \\
\hline Material & Aluminum & Aluminum & $\begin{array}{c}\text { Copper tubes and } \\
\text { Aluminum fins }\end{array}$ & $\begin{array}{c}\text { Copper tubes and } \\
\text { Aluminum fins }\end{array}$ \\
\hline
\end{tabular}

Small heat exchangers do provide the required thermal performance, they are not cost effective, and hence a low cost and high thermal capacity automobile radiator is purchased for the thesis experimental investigation.

\subsection{Component Selection}

A $370 \mathrm{~W}$ pump of maximum flow rate $6.33 \mathrm{gpm}$ having maximum head of 18 meter is purchased with a high temperature vacuum coolant hose of length 2 meter and 0.019 meter diameter shown in Figure 7 

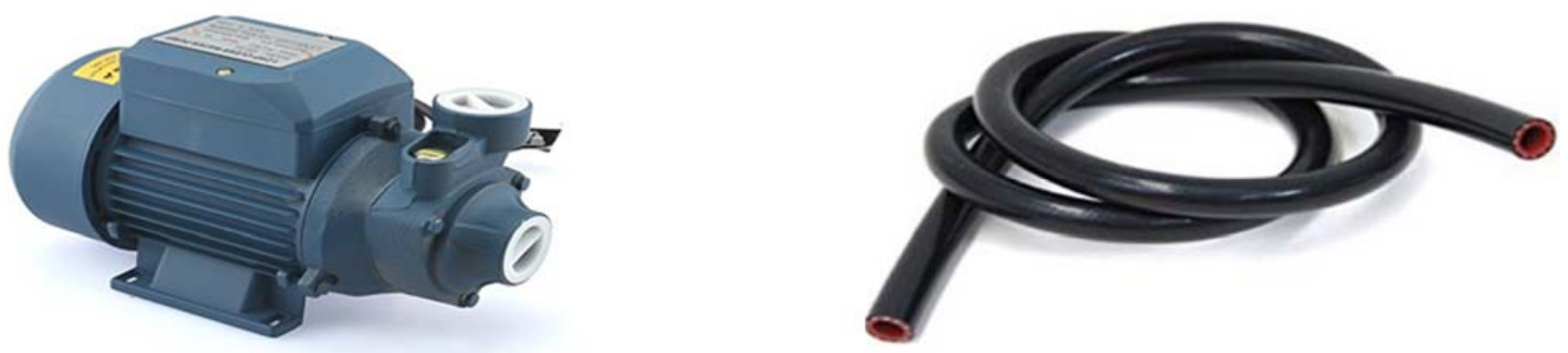

Figure 7. Pump and Hose.

A Honda civic 2000 radiator selected for the application is shown in Figure 8.

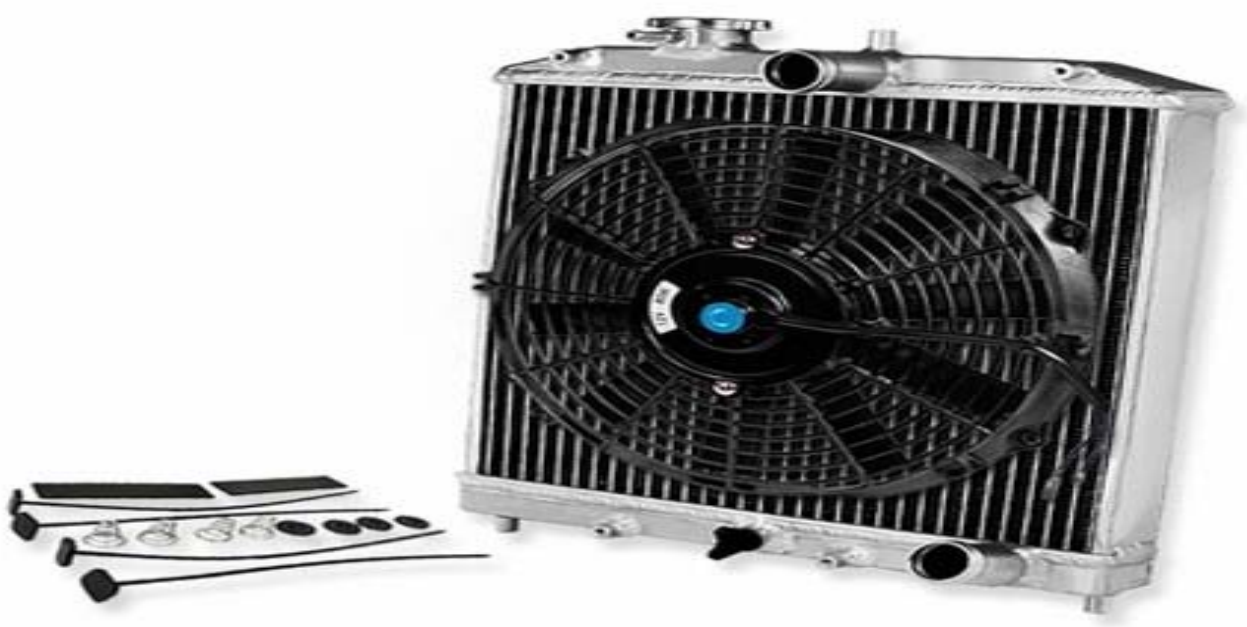

Figure 8. 2 Rows aluminum Honda radiator. 


\section{Chapter 4 Experimental Set up}

\subsection{Design of Test Rig}

An experimental test rig is designed using SOLIDWORKS. This robust, portable strut stand accommodates the required components of the cooling system and eliminates the issue of immobility. The designed test rig is shown in Figure 9. For the thesis though, heat exchanger installed on this strut stand was tested, but it has the capacity to test the entire cooling system.

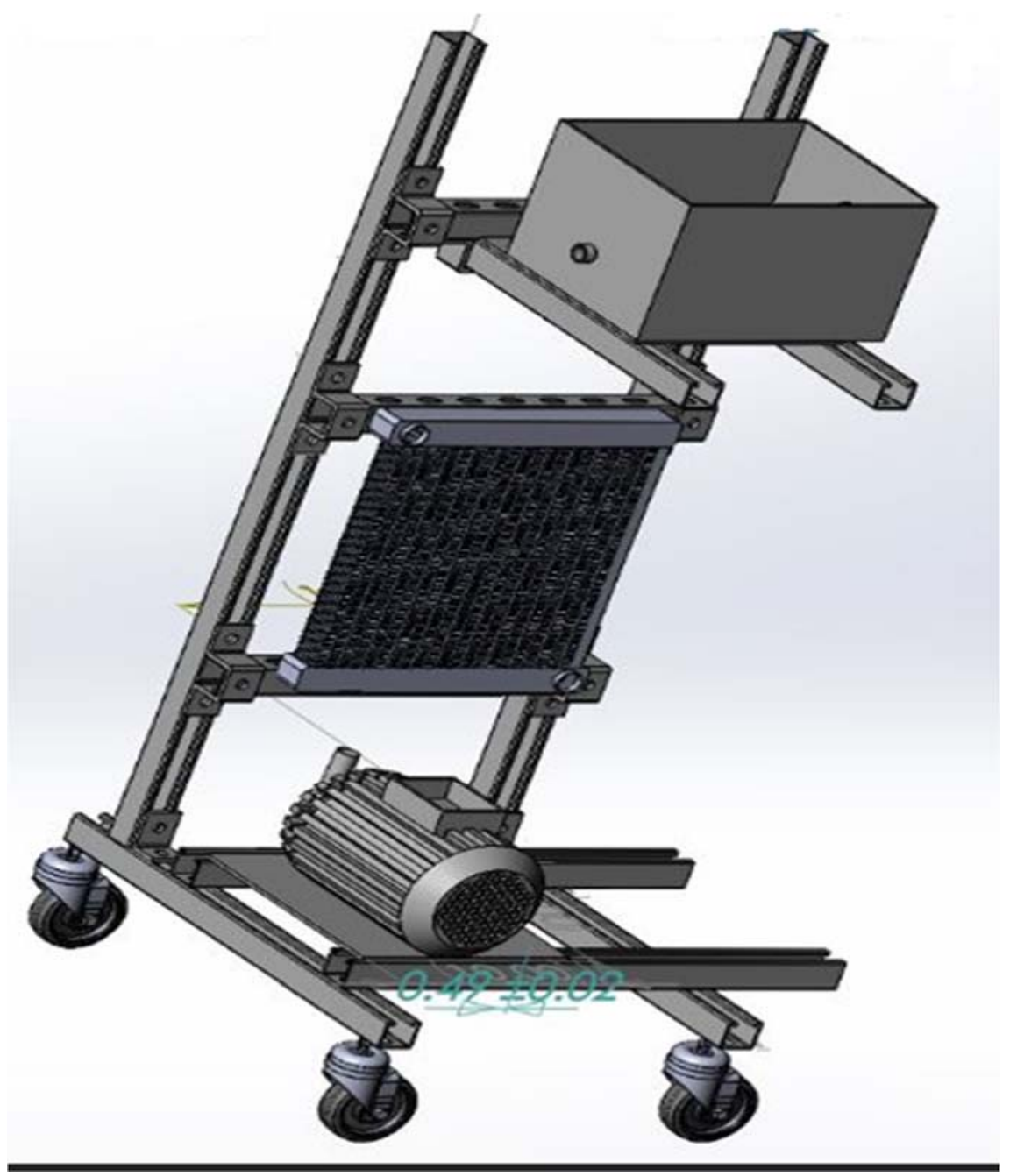

Figure 9. Solidworks view of the test rig. 


\section{Strut Channel Configuration}

Careful considerations of strut channels were done before being procured from McMaster-Carr. Aluminum alloy strut channels were chosen because of high strength, corrosion resistant and less weight (almost half the weight of steel strut channels). The holes on the strut channel facilitates interconnection and fastening of struts, which eases the effort to mount/fix mechanical components. Strut channels are assembled rapidly with minimum tools, reducing the overall fabrication cost.

Elliptical hole patterns of width 9/16 inch and length 1-1/8 inch are common in slotted type strut channel. Unlike solid channels where holes need to be drilled, slotted channels have pre-drilled holes of standardized sizes. Knowing its benefits, 5 slotted channels of length 4 feet, were selected.

\section{Connectors, Nuts, Screws and Casters configuration}

U shaped connectors, 90-degree angle connectors, head hex screw and unistrut channel nuts are utilized to connect various strut channels with each other. $U$ shaped and 90-degree angle connectors perfectly fit the application and are made up of zinc plated steel as it offers good corrosion resistance. Spring nuts also called as speed nuts, have serrated grooves that grip the lip of the channel and provide a more secure hold than standard strut channel nuts. It helps to pull out and side slip beyond the normal strength of the channels. Like connectors, these nuts are also made up of zinc plated steel. Additionally, screws are used to lock these spring nuts. They fit all the 1$5 / 8$-inch cross section strut channel. Head screws selected were also of zinc plated steel and it offered $25 \%$ more strength than the medium strength steel screws. Table 11 and Table 12 summarizes the technical specifications of the strut stand assembly.

Table 11. Component specification 1.

\begin{tabular}{|c|c|c|c|c|}
\hline \multirow{2}{*}{ Components } & \multicolumn{4}{|c|}{ Specification } \\
\cline { 2 - 5 } & Width & Height & Tread Size & Material \\
\hline Spring Nuts- 15 & $15 / 8^{\prime \prime}$ & $15 / 8^{\prime \prime}$ & $5 / 16^{\prime \prime}$ & Zinc plated steel \\
\hline Hex Head Screw- 15 & $1 / 2^{\prime \prime}$ & $7 / 32^{\prime \prime}$ & $5 / 16^{\prime \prime}$ & Zinc plated steel \\
\hline
\end{tabular}


Table 12. Component specification 2.

\begin{tabular}{|c|c|c|c|c|c|c|c|}
\hline \multicolumn{2}{|c|}{ Components } & \multicolumn{6}{|c|}{ Specification } \\
\cline { 2 - 8 } & Length & Height & Width & Thickness & Hole Diameter & Material \\
\hline \multirow{4}{*}{ Connectors } & $\begin{array}{c}\mathrm{U} \\
\text { shaped-5 }\end{array}$ & $53 / 8^{\prime \prime}$ & $15 / 8^{\prime \prime}$ & $15 / 8 "$ & $1 / 4 "$ & $9 / 16^{\prime \prime}$ & $\begin{array}{c}\text { Zinc plated } \\
\text { steel }\end{array}$ \\
\cline { 2 - 8 } & $\begin{array}{c}90^{\circ} \\
\text { angle-5 }\end{array}$ & $21 / 4 "$ & $15 / 8^{\prime \prime}$ & $15 / 8 "$ & $1 / 4 "$ & $9 / 16^{\prime \prime}$ & $\begin{array}{c}\text { Zinc plated } \\
\text { steel. }\end{array}$ \\
\hline
\end{tabular}

Finally, casters were used to mobilize strut channel assembly. Casters have a specialized designed polypropylene stem that slides into the slotted strut channels. It is available in both swivel and rigid styles having load rating up to $250 \mathrm{lbs}$. Four swivel strut casters were chosen to maneuver the test stand effectively. A testing equipment built can be seen in the Figure 10.

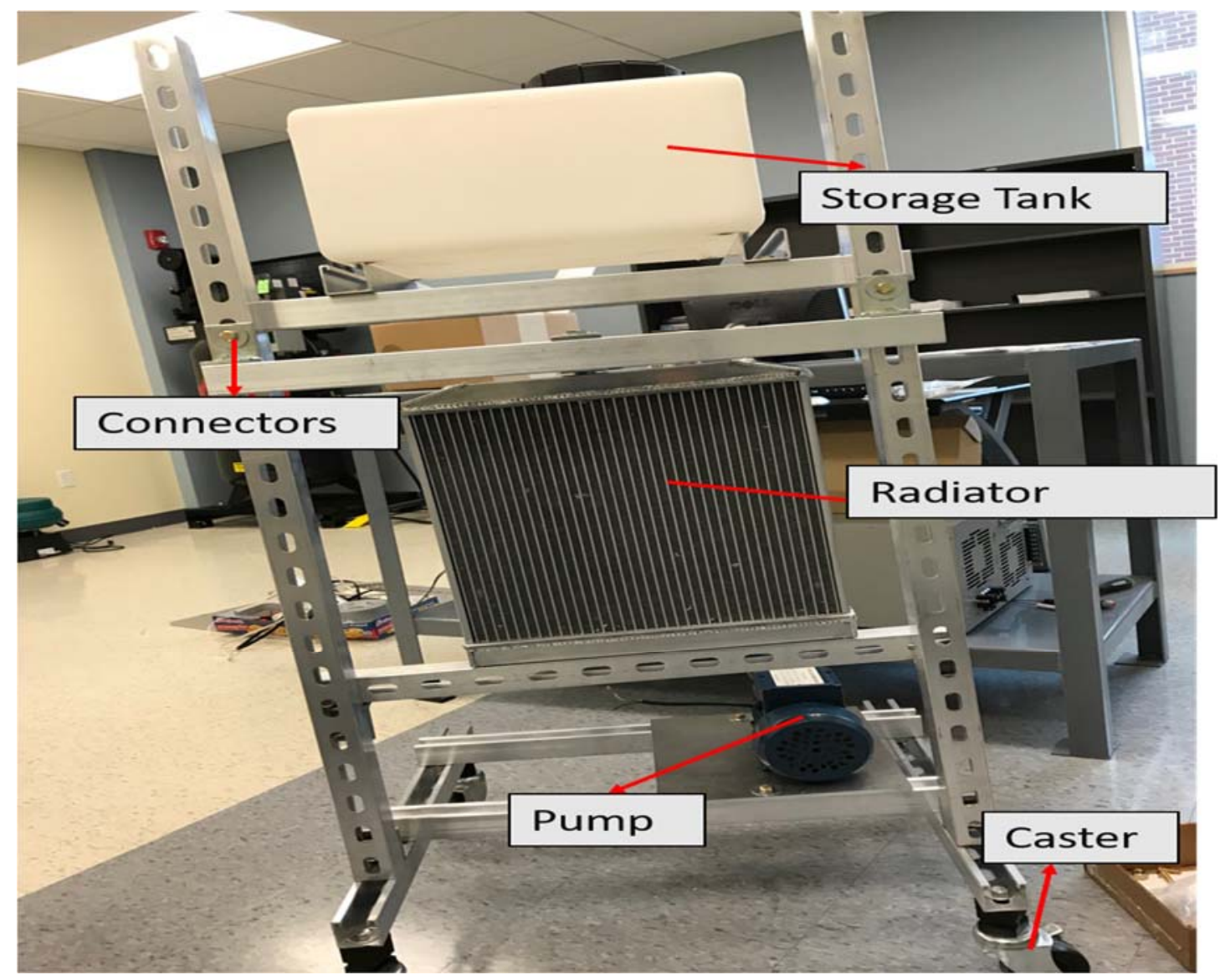

Figure 10. Front view of the test rig. 


\subsection{Testing Equipment and Measuring Instruments}

An aluminum downflow radiator manufactured by ASI performance which fits the 2000 model of honda civic is purchased. An aluminum core design having inlet and outlet of 1.26 inches with a core size of 14.09 inches height and 13.78 inches width. It also includes a 12 inches diameter fan, having maximum flow rate of 1730 cubic feet per minute (cfm). Fan has 10 blades with a maximum speed of $2250 \mathrm{rpm}$. An adapter convertor of 120 Watts is used to power the DC fan. A mini DC voltage regulator is also used to control the fan's speed, as volume flow rate of the fan is too high. View of the radiator mounted on the strut stand is shown in the Figure 11.

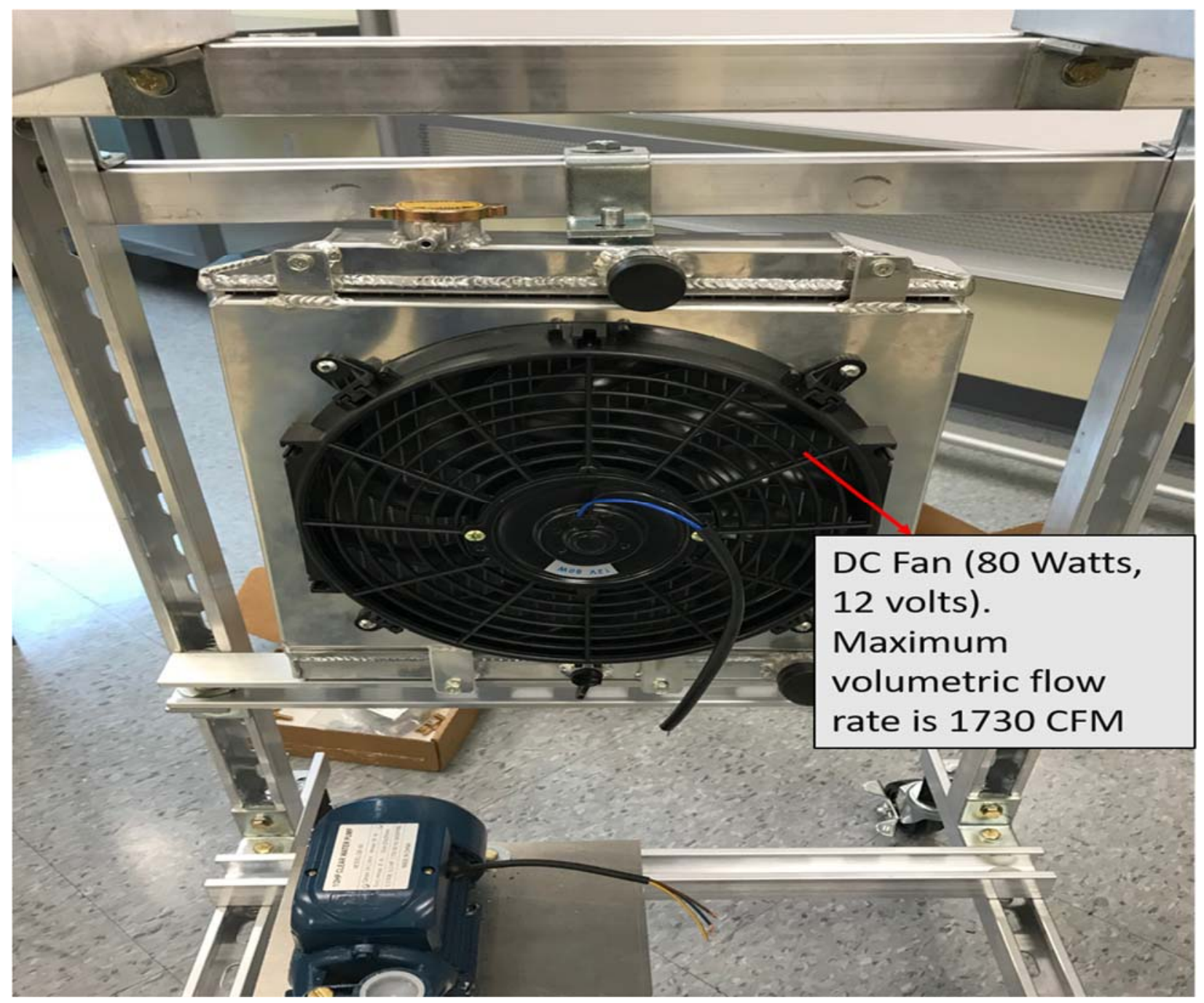

Figure 11. Radiator and fan assembly. 


\section{Instruments Measuring Temperature and Mass Flow Rate}

The Omega HH12B model number handheld thermometer is obtained for testing. This thermometer features type $\mathrm{k}$ thermocouple inputs. It is a dual input meter that allows to display temperature reading from two thermocouples and also measures its difference $\left(\mathrm{T}_{1}-\mathrm{T}_{2}\right) 1^{\mathrm{o}}$ resolution. There is a front panel offset adjustment feature which practically eliminates the errors over limited measurement range and has a maximum reading hold function. Specification is mentioned in the table below.

Table 13. Omega Handheld Thermometer.

\begin{tabular}{|l|l|}
\hline \multicolumn{1}{|c|}{ Specification } & \multicolumn{1}{c|}{ Value } \\
\hline Measurement Range & $-50^{\circ} \mathrm{C}$ to $1300^{\circ} \mathrm{C}$ \\
\hline Accuracy & $\pm 0.3 \% \mathrm{rdg}+1^{\circ} \mathrm{C}$ \\
\hline Battery & 9 volts \\
\hline
\end{tabular}

K type thermocouple probe selected for liquid temperature measurement has a temperature range of $-198^{\circ} \mathrm{C}$ to $926^{\circ} \mathrm{C}$, whereas the one selected for air temperature measurement has a range of $248^{\circ} \mathrm{C}$ to $121^{\circ} \mathrm{C}$ with $\pm 2.5^{\circ} \mathrm{C}$ accuracy. For wall temperature measurement, an infrared laser thermometer is obtained. It is useful for measuring temperature under circumstances where thermocouples or other probe-type sensors cannot be used or do not produce accurate data for variety of reasons. A non-contact infrared thermometer which has measurement range of $-50^{\circ} \mathrm{C}$ to $380^{\circ} \mathrm{C}$ is used and depicted in Figure 12. It also has an auto shut-off and data hold function.

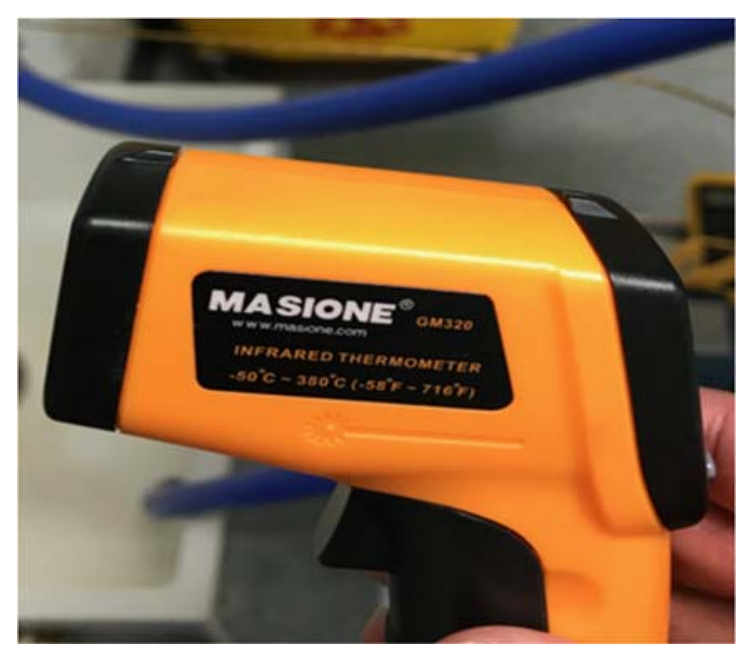

Figure 12. Infrared thermometer. 
AN-100 mini thermo-anemometer is used to measure the speed of the fan in cubic feet per minute $(\mathrm{cfm})$. Volumetric flow rate is determined if the area is known. Air flow rate is measured by taking average of 20 values measured at 20 different points at the frontal area of the fan with an accuracy of $\pm 3 \% \frac{f t^{3}}{\min }$ shown in Figure 13 .

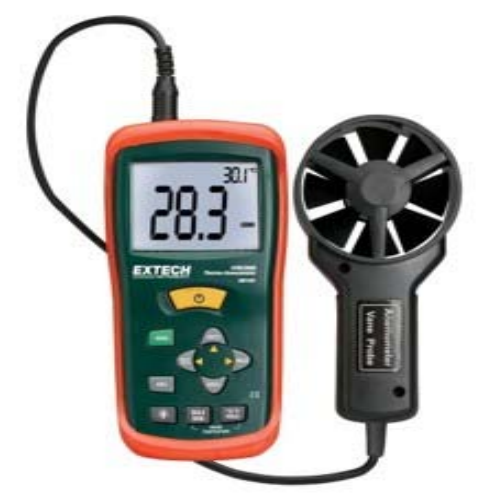

Figure 13. Thermo-anemometer.

Volumetric flow rate of water is measured by using a bucket method. It is one of the simple methods to measure the liquid flow rate. It requires a large bucket with measuring scale and stop watch. The discharge rate is calculated by drawing the water in a bucket and gauging the time it takes to fill the bucket of known volume. For accuracy, this procedure was repeated 3 times to get an average volumetric flow rate. The variation in filling times during different measurements give a better understanding of the accuracy. For higher flow rates, using rotameters and other techniques is recommended.

\subsection{Testing Procedure}

In this research, the Heat exchanger is connected to a source of hot water through hose. A ball valve is installed between a hose and heat exchanger, which made it easier to measure the volumetric flow rate of hot water by the bucket method. Two thermocouples are installed at the inlet and exit of the heat exchanger to measure the inlet and exit temperature of hot water. Thermocouple installed in the hose at the inlet of the radiator was approximately 10 inches away from the inlet whereas thermocouple at the exit was installed 2 inches away from the radiator's outlet. The hot water is naturally fed to the heat exchanger from the source and flows through its core. To measure the temperature of the hot air exiting the heat exchanger, another thermocouple is installed at the fan's vent. The tube wall temperature of the heat exchanger is measured by using an infrared thermometer at different wall points. The water flow rate is kept constant for the first 
round of data. The hot water is made to flow through the heat exchanger and then sink until the hot water becomes steady and the temperature variations at the inlet and outlet are not more than $\pm 2^{\circ} \mathrm{C}$. The fan's flow rate is set constant and recorded at $682 \mathrm{cfm}$. The flow rate of hot water is varied at constant air flow rate to analyze its effects on the exit temperature. The above procedure of measuring the inlet and outlet water temperature and fan's flow rate is repeated once reaching steady state for the changed flow rate. The first set of data corresponds to six different water flow rates, keeping the initial conditions the same. Likewise, four set of data is obtained for different air and water flow rates for a temperature range of $68^{\circ} \mathrm{C}$ to $75^{\circ} \mathrm{C}$, whereas at lower temperatures $\left(40^{\circ} \mathrm{C}\right.$ to $50^{\circ} \mathrm{C}$.), only one set of data is measured over six different water flow rates at constant air flow rate [22]. Figure 14 shows the experimental set-up in thermo-fluids lab with the digital thermometer, thermocouple and hoses.

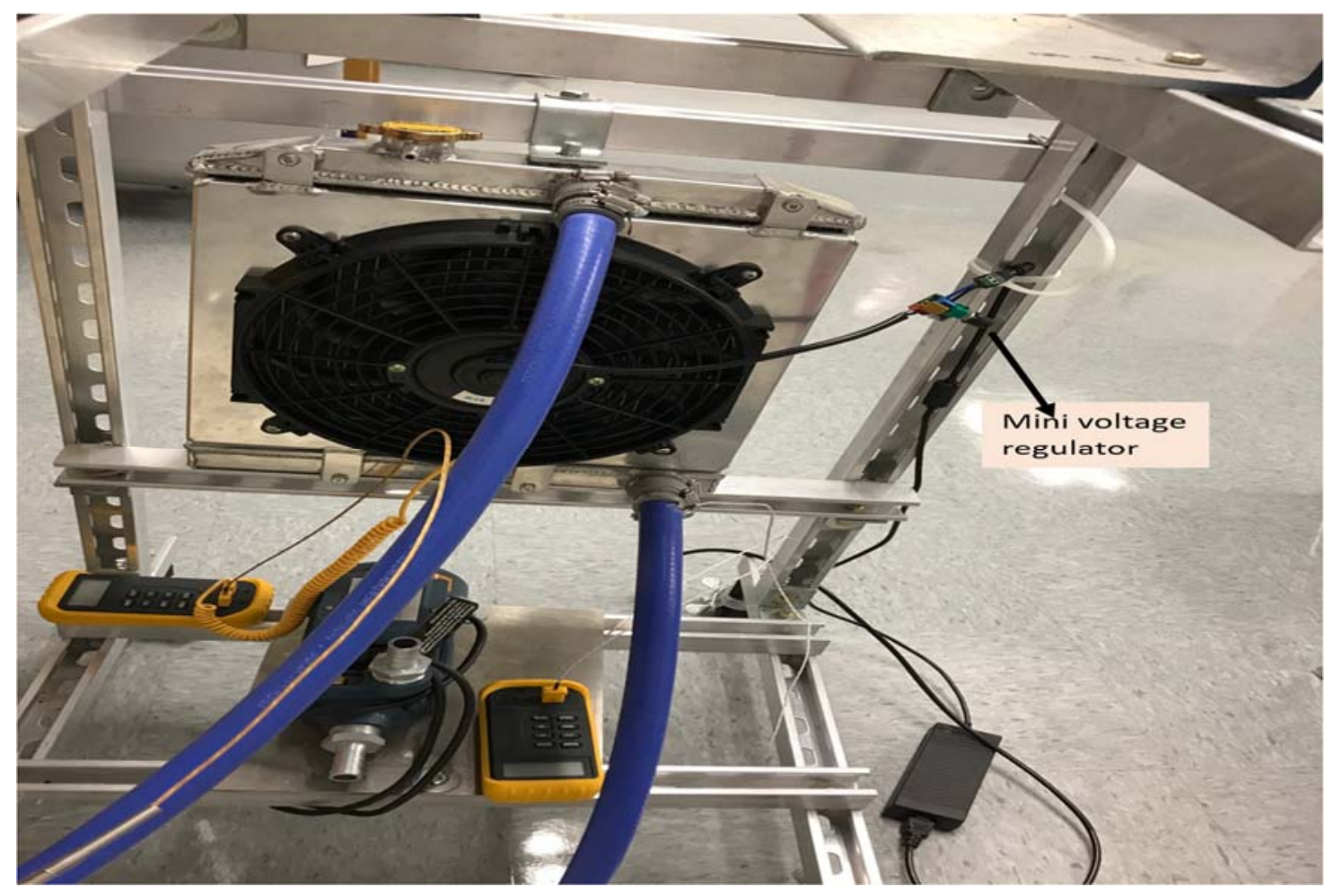

Figure 14. Experimental set up in thermo- fluids lab. 
The results for the experimental data are obtained based on the following assumptions:

- Velocity and temperature at the inlet of the radiator on the air and liquid side are uniform.

- Water flow rate is uniformly distributed through the tubes in each pass. No stratification, flow bypassing or flow leakages occur in any stream.

- Flow is characterized as a bulk fluid at all cross section.

- Fluid's temperature is considered to be uniform over every flow cross section.

- For constant mass flow rate of water, heat transfer coefficient between water and tube is uniform.

- The tube thickness is very small. Hence, conduction resistance through the tubes is negligible.

- Heat transfer area is uniformly distributed on each side. 


\section{Chapter 5 Results and Discussions}

The following mathematical relations are used to perform heat transfer analysis for the collected experimental data. According to Newton's law of cooling,

$$
Q=h_{w} \times A_{s t} \times\left(T_{b w}-T_{w}\right)=h_{\text {air }} \times A_{s f} \times\left(T_{w}-T_{\text {bair }}\right)
$$

$A_{s t}$ is the total surface area of the tube, $A_{s f}$ is the total surface area fin side, $T_{w}$ is the tube wall temperature measured at different points and $\mathrm{T}_{\mathrm{bw}}$ is the bulk temperature for water side and $\mathrm{T}_{\mathrm{bair}}$ is the bulk temperature for air side defined by,

$$
T_{b}=\frac{T_{\text {in }}+T_{\text {out }}}{2}
$$

Firstly, heat transfer rate at both air and water side is calculated by energy balance equations,

$$
\begin{aligned}
& Q=m_{w} \times C_{p w} \times \Delta T=m_{w} \times C_{p w} \times\left(T_{\text {inw }}-T_{\text {outw }}\right) \\
& Q=m_{a} \times C_{p a} \times \Delta T=m_{a} \times C_{p a} \times\left(T_{\text {outa }}-T_{\text {ina }}\right)
\end{aligned}
$$

Mass flow rate for both air and water side is obtained by

$$
m=\rho \times V
$$

$\mathrm{V}$ is the volumetric flow rate and the heat transfer coefficient is evaluated as

$$
\begin{array}{r}
h_{w}=\frac{m_{w} \times C_{p w} \times\left(T_{\text {inw }}-T_{\text {outw }}\right)}{A_{s t} \times\left(T_{b w}-T_{w}\right)} \\
h_{\text {air }}=\frac{m_{a} \times C_{p a} \times\left(T_{\text {outa }}-T_{\text {ina }}\right)}{A_{s f} \times\left(T_{w}-T_{\text {bair }}\right)}
\end{array}
$$

The Nusselt and Reynolds number is calculated as

$$
\begin{gathered}
N_{u}=\frac{h \times D_{h}}{k} \\
R_{e}=\frac{\rho \times v \times D_{h}}{\mu}
\end{gathered}
$$


Where $\mathrm{D}_{\mathrm{h}}$ is the hydraulic diameter obtained by

$$
D_{h}=\frac{4 \text { Area }}{\text { Perimeter }}
$$

For liquid side, $\mathrm{D}_{\mathrm{h}}$ is calculated by using tube dimensions and value of $\mathrm{D}_{\mathrm{h}}$ for the air side is calculated by fin dimensions, as air passes through the passages created by the fin geometry. The schematic for the fin and tube geometry is shown in Figure 15 [17].
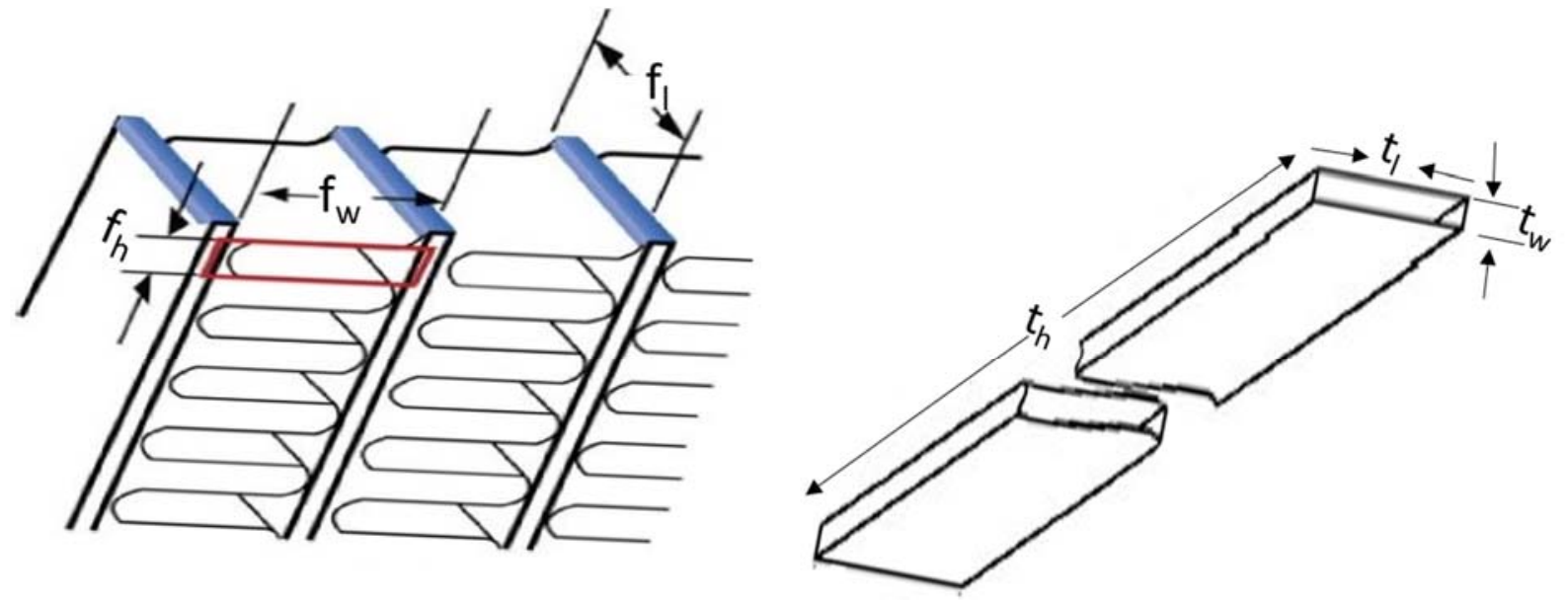

Figure 15. Schematic of the geometry of tube and fin of the heat exchanger [17]. 
Dimensions of the radiator are carefully measured. Important geometric characteristics of the water and air side is calculated and tabulated in Table 14.

Table 14. Radiator core configurations reference.

\begin{tabular}{|c|c|}
\hline Data & Value \\
\hline Number of Rows & 2 \\
\hline Core width $\left(\mathrm{w}_{\mathrm{c}}\right)$ & $0.350 \mathrm{~m}$ \\
\hline Core height $\left(\mathrm{h}_{\mathrm{c}}\right)$ & $0.357 \mathrm{~m}$ \\
\hline Core thickness $\left(t_{c}\right)$ & $0.035 \mathrm{~m}$ \\
\hline Total cross-sectional area $\left(\mathrm{A}_{c}\right)$ & $0.125 \mathrm{~m}^{2}$ \\
\hline Tube width $\left(\mathrm{w}_{\mathrm{t}}\right)$ & $0.001 \mathrm{~m}$ \\
\hline Tube height $\left(\mathrm{h}_{\mathrm{t}}\right)$ & $0.357 \mathrm{~m}$ \\
\hline Tube length $\left(l_{t}\right)$ & $0.017 \mathrm{~m}$ \\
\hline Total cross-sectional area of the tube $\left(\mathrm{A}_{\mathrm{ct}}\right)$ & $1.8 \mathrm{E}-3 \mathrm{~m}^{2}$ \\
\hline Total surface area of the tube $\left(\mathrm{Ast}_{\mathrm{st}}\right)$ & $0.966 \mathrm{~m}$ \\
\hline No of tubes ( $\mathrm{n}_{\text {tube) }}$ & 70 \\
\hline Hydraulic diameter tube side $\left(\mathrm{D}_{\mathrm{ht}}\right)$ & $0.0027 \mathrm{~m}$ \\
\hline Fin width $(\mathrm{wf})$ & $0.009 \mathrm{~m}$ \\
\hline Fin height $\left(\mathrm{h}_{\mathrm{f}}\right)$ & $0.001 \mathrm{~m}$ \\
\hline Fin length $\left(l_{\mathrm{f}}\right)$ & $0.035 \mathrm{~m}$ \\
\hline Total cross-sectional area of the fin $\left(\mathrm{A}_{\text {cfin }}\right)$ & $0.110 \mathrm{~m}^{2}$ \\
\hline Total surface area of the fin $\left(\mathrm{A}_{\mathrm{sf}}\right)$ & $6.910 \mathrm{~m}^{2}$ \\
\hline No of passages $\left(\mathrm{n}_{\mathrm{p}}\right)$ & 10435 \\
\hline Hydraulic diameter fin side (Dhfin) & $0.0021 \mathrm{~m}$ \\
\hline
\end{tabular}

The summary of the cases investigated during experimental test is presented in Table 15. The experimental results obtained by using water as a coolant at constant air flow rate are reported in Table 16. The other set of data is reported in the appendix. 
Table 15. List of cases tested.

\begin{tabular}{|l|l|l|l|}
\hline Coolant's inlet temperature & 68 to $75^{\circ} \mathrm{C}$ & 39 to $41^{\circ} \mathrm{C}$ & 50 to $51^{\circ} \mathrm{C}$ \\
\hline Air's inlet temperature & $21.7^{\circ} \mathrm{C}$ & $21.7^{\circ} \mathrm{C}$ & $21.7^{\circ} \mathrm{C}$ \\
\hline Coolant's flow rate & 1 to $6 \mathrm{gpm}$ & 0.5 to $5 \mathrm{gpm}$ & 0.5 to $5 \mathrm{gpm}$ \\
\hline Air's flow rate & 682 to $394 \mathrm{cfm}$ & $572.9 \mathrm{cfm}$ & $572.9 \mathrm{cfm}$ \\
\hline Coolant used & water & water & water \\
\hline
\end{tabular}

Table 16. Effect of coolant's (water) flow rate on heat transfer rate (water side) and other parameters at constant air flow rate of $572.9 \mathrm{cfm}$.

\begin{tabular}{|c|c|c|c|c|c|c|c|c|c|c|c|}
\hline $\begin{array}{c}\mathrm{V}_{w} \\
(\mathrm{gpm})\end{array}$ & $\begin{array}{c}\mathrm{m}_{\mathrm{w}} \\
(\mathrm{kg} / \mathrm{sec})\end{array}$ & $\begin{array}{c}\mathrm{T}_{\mathrm{in}, \mathrm{w}} \\
\left({ }^{\circ} \mathrm{C}\right)\end{array}$ & $\begin{array}{c}\mathrm{T}_{\mathrm{out}, \mathrm{w}} \\
\left({ }^{\circ} \mathrm{C}\right)\end{array}$ & $\begin{array}{c}\mathrm{T}_{\mathrm{in}, \mathrm{a}} \\
\left({ }^{\circ} \mathrm{C}\right)\end{array}$ & $\begin{array}{c}\mathrm{T}_{\text {out,a }} \\
\left({ }^{\circ} \mathrm{C}\right)\end{array}$ & $\begin{array}{c}\mathrm{T}_{\mathrm{w}} \\
\left({ }^{\circ} \mathrm{C}\right)\end{array}$ & $\begin{array}{c}\mathrm{Q}_{\mathrm{w}} \\
(\mathrm{W})\end{array}$ & $\begin{array}{c}\mathrm{h}_{\mathrm{w}}(W / \\
\left.m^{2} \mathrm{C}\right)\end{array}$ & $\mathrm{Re}_{\mathrm{w}}$ & $\mathrm{Nu}_{\mathrm{w}}$ & $\mathrm{Pr}_{\mathrm{w}}$ \\
\hline 1.05 & 0.065 & 68.3 & 58.2 & 21.7 & 43.4 & 58.5 & 2748.1 & 598.9 & 212.7 & 2.5 & 2.8 \\
\hline 2.45 & 0.152 & 69.3 & 61.2 & 21.7 & 56.2 & 59.9 & 5155.0 & 997.5 & 520.3 & 4.2 & 2.7 \\
\hline 3.27 & 0.203 & 71.4 & 63.5 & 21.7 & 55.4 & 61.7 & 6717.9 & 1209.5 & 733.8 & 5.1 & 2.5 \\
\hline 3.98 & 0.247 & 71.5 & 63.9 & 21.7 & 55.6 & 61.8 & 7863.6 & 1379.7 & 906.1 & 5.8 & 2.5 \\
\hline 4.33 & 0.269 & 71.4 & 64.7 & 21.7 & 60.4 & 62.7 & 7549.8 & 1460.9 & 986.8 & 6.1 & 2.5 \\
\hline & & & & & & & & & & & \\
\hline 5.90 & 0.366 & 71.2 & 65.4 & 21.7 & 59.8 & 62.2 & 8894.5 & 1509.4 & 1342.7 & 6.3 & 2.5 \\
\hline
\end{tabular}

\subsection{Effect of water flow rate on heat transfer rate at different air flow rate}

Figure 16 shows the effect of water flow rate and air flow rate on the heat transfer rate. As expected, increasing air and water flow rate was found to increase the heat transfer rate. It is because of the fact that as air flow rate increases, the temperature of water inside the tubes decreases, resulting in higher dissipation rate, whereas decreasing air flow rate decreases the heat transfer from water to air, increasing water's exit temperature. 


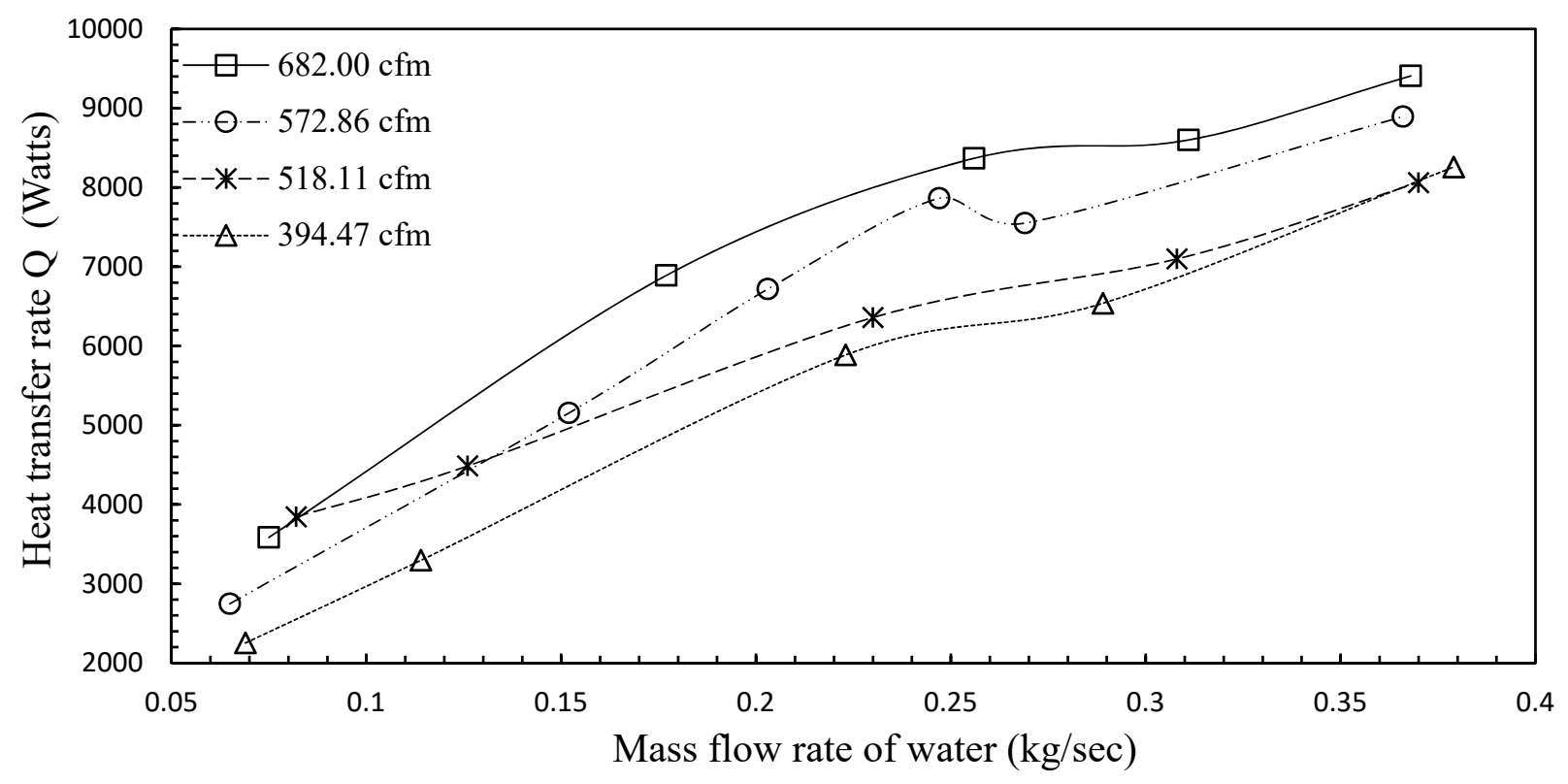

Figure 16. Effect of water and air flow rate on heat transfer rate (water side).

\subsection{Effect of water flow rate on heat transfer rate and heat transfer coefficient at different temperatures at constant air flow rate.}

An increased value of heat transfer rate is observed at $70^{\circ} \mathrm{C}$ than $50^{\circ} \mathrm{C}$ and $40^{\circ} \mathrm{C}$ at constant air flow rate of $572.9 \mathrm{cfm}$ and shown in Figure 17. This is because, rate of heat transfer is always directly proportional to the temperature difference and specific heat. In case of $70^{\circ} \mathrm{C}$ of water's inlet temperature, a higher temperature difference is observed accompanied with higher specific heat capacity of water.

Figure 18 shows the variation in heat transfer coefficient with respect to change in mass flow rate of water at constant air flow rate $(572.9 \mathrm{cfm})$. Higher values of heat transfer coefficient is observed at increased inlet temperature and increased flow rate. 


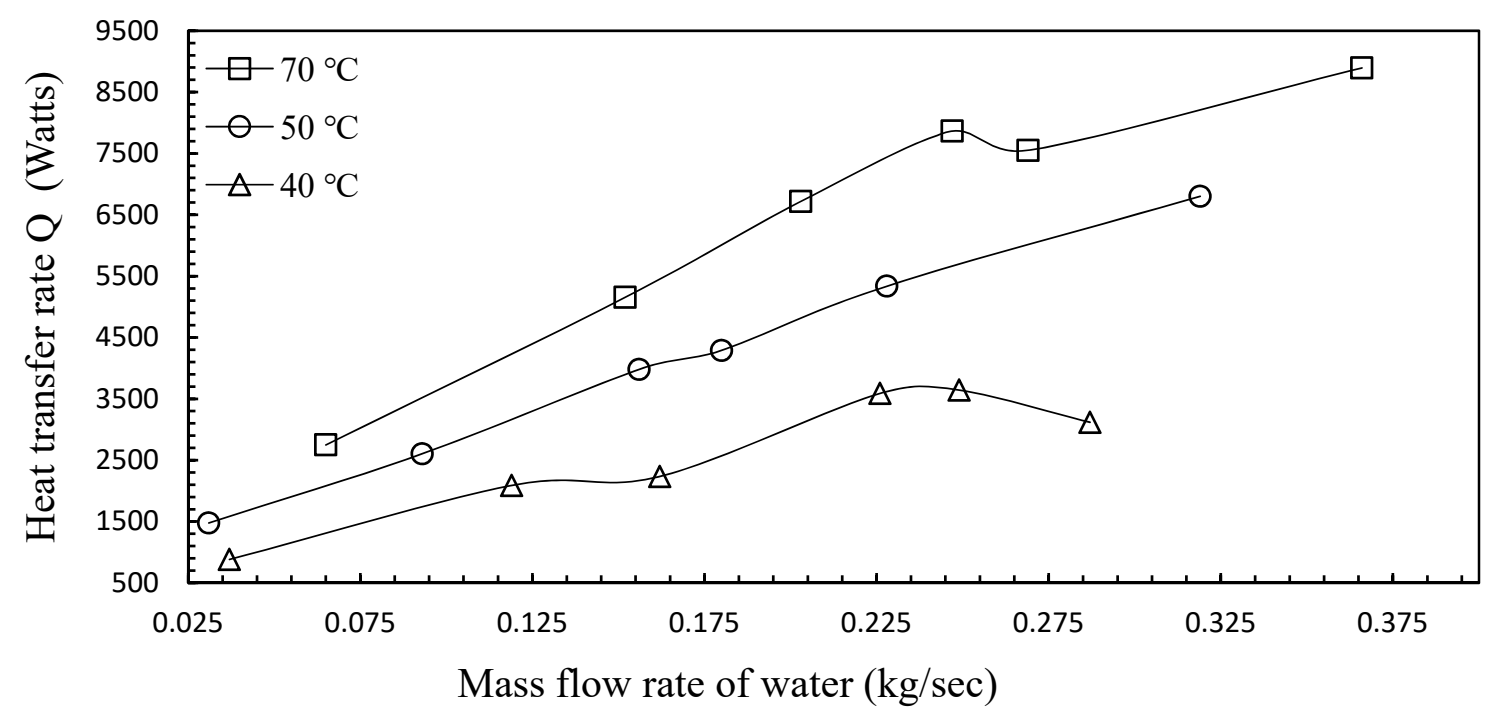

Figure 17. Effect of water flow rate and inlet temperature of water on heat transfer rate at air flow rate of $572.9 \mathrm{cfm}$.

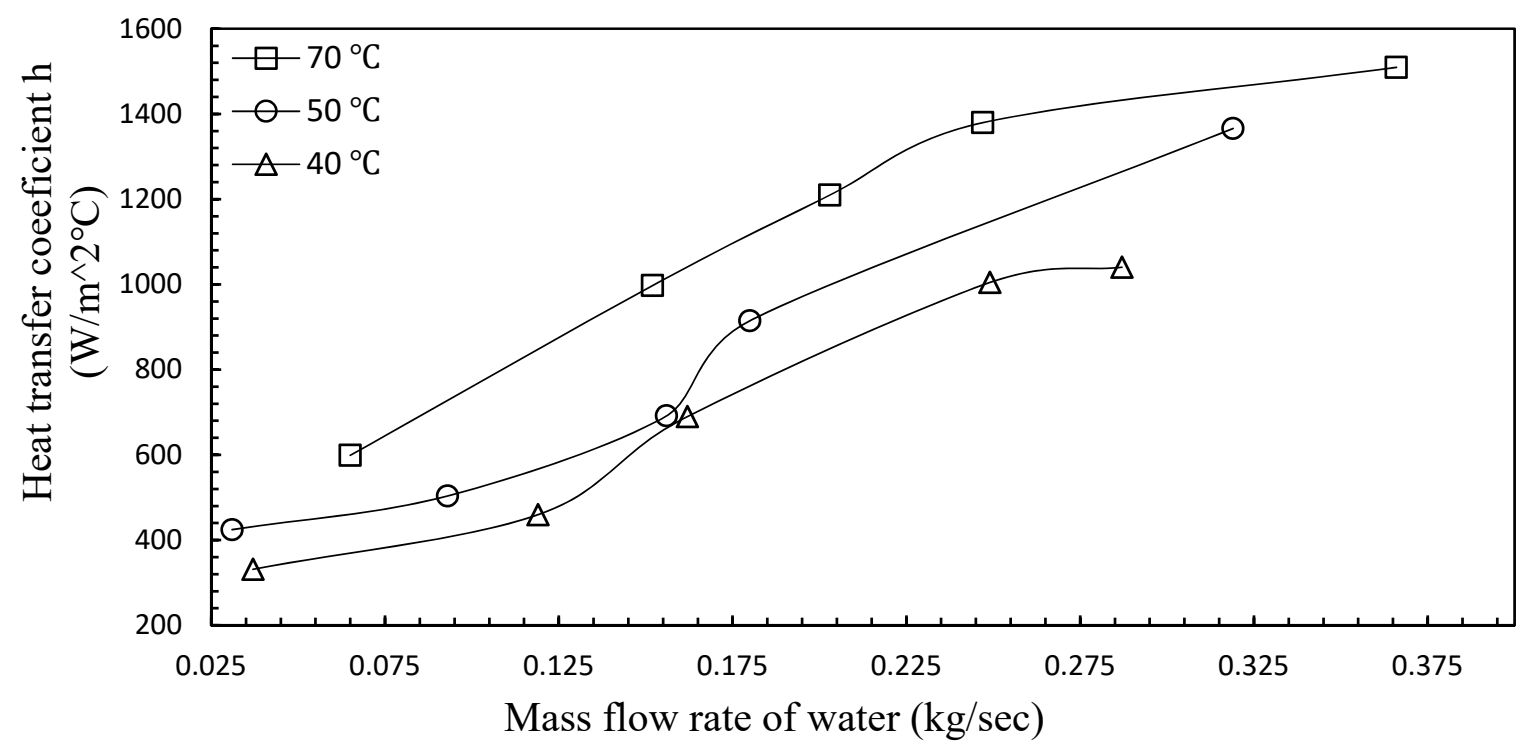

Figure 18. Effect of water flow rate and inlet temperature of water on heat transfer coefficient at air flow rate of $572.9 \mathrm{cfm}$. 


\subsection{Effect of Reynolds number and Prandtl number on Nusselt number for water side}

It is observed that Nusselt number for water increases with increase in mass flow rate of water and increased temperature at constant air flow rate of $572.9 \mathrm{cfm}$. This is due to the increase in Reynolds number accompanied with increased in water flow rate and decreased viscosity. Nusselt number is a function of Reynolds number and Prandtl number. Therefore, the overall effect of dimensionless numbers (Reynolds and Prandtl number) on Nusselt number is investigated at $40^{\circ} \mathrm{C}$, $50^{\circ} \mathrm{C}$, and $70^{\circ} \mathrm{C}$ and illustrated in Figure 19.

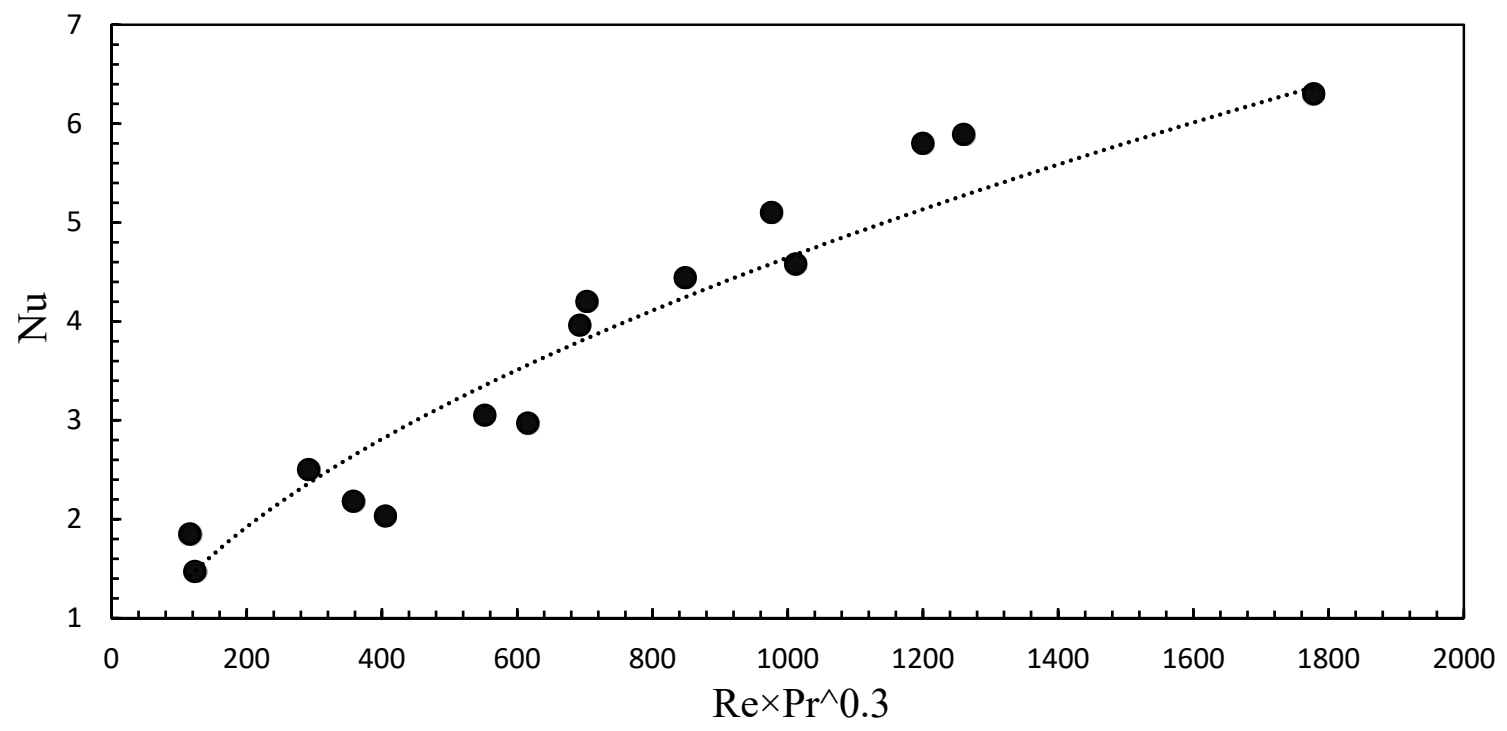

Figure 19. Effect of Reynolds and Prandtl numbers on Nusselt number (water side) at water inlet temperature of $40^{\circ} \mathrm{C}, 50^{\circ} \mathrm{C}$ and $70^{\circ} \mathrm{C}$

Figure 20 shows the effect of Reynolds and Prandtl number on Nusselt number for water side with the variation in air flow rate from 682 to $394 \mathrm{cfm}$, at the inlet temperature of water in the range of 68 to $75^{\circ} \mathrm{C}$, at water flow rate from 1 to $6 \mathrm{gpm}$. The Nusselt number of water increases with increase in water flow rate and air flow rate. As increase in flow rates of both the fluids, increase the heat transfer rate and heat transfer coefficient for water side. 


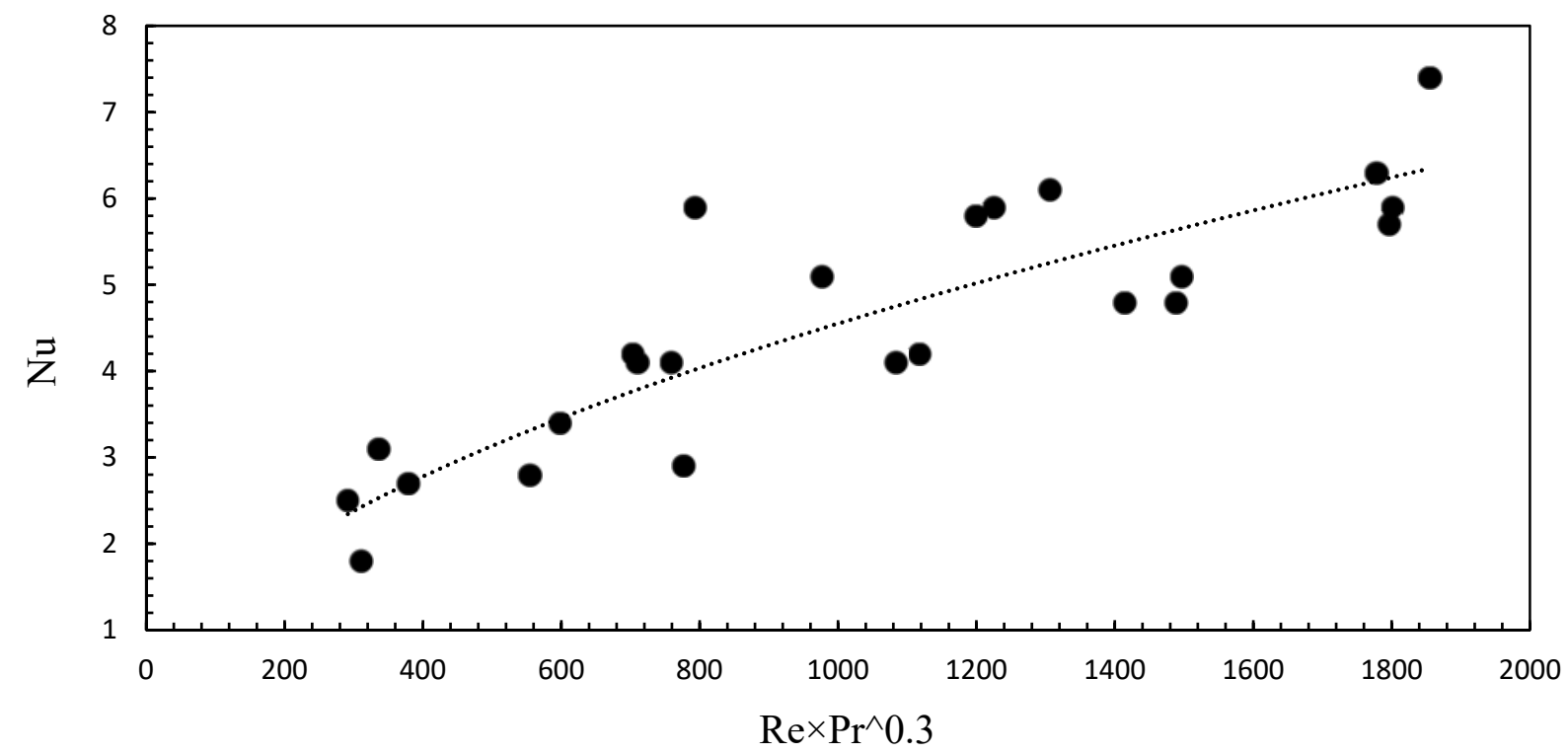

Figure 20. Effect of Reynolds and Prandtl numbers on Nusselt number (water side) at $70{ }^{\circ} \mathrm{C}$ of water inlet temperature.

So far, several empirical equations have been developed to predict the Nusselt number in liquids in thermally developing region under laminar flow regime. Similarly, an empirical correlation is developed for the collected experimental data and proposed for this geometry of heat exchanger and illustrated in Figure 21. The effect of Reynolds and Prandtl number on Nusselt number for water side with the temperature variation from $\left(40^{\circ} \mathrm{C}\right.$ to $\left.70^{\circ} \mathrm{C}\right)$ as well as variation of air flow rate from 682 to $394 \mathrm{cfm}$ is shown in Figure 21. The correlation which is developed is valid for water at temperature range of $40^{\circ} \mathrm{C}$ to $70^{\circ} \mathrm{C}$ in the developing region for the tubes of the heat exchanger for laminar flow in the range of $80 \leq \mathrm{R}_{\mathrm{ew}} \leq 1400$. The correlation is in the following form,

$$
\begin{gathered}
N_{u}=a \times R_{e}^{b} \times P_{r}^{0.3} \\
N_{u w}=0.11 \times R_{e w}^{0.54} \times P_{r w}^{0.3}, R^{2}=0.85
\end{gathered}
$$




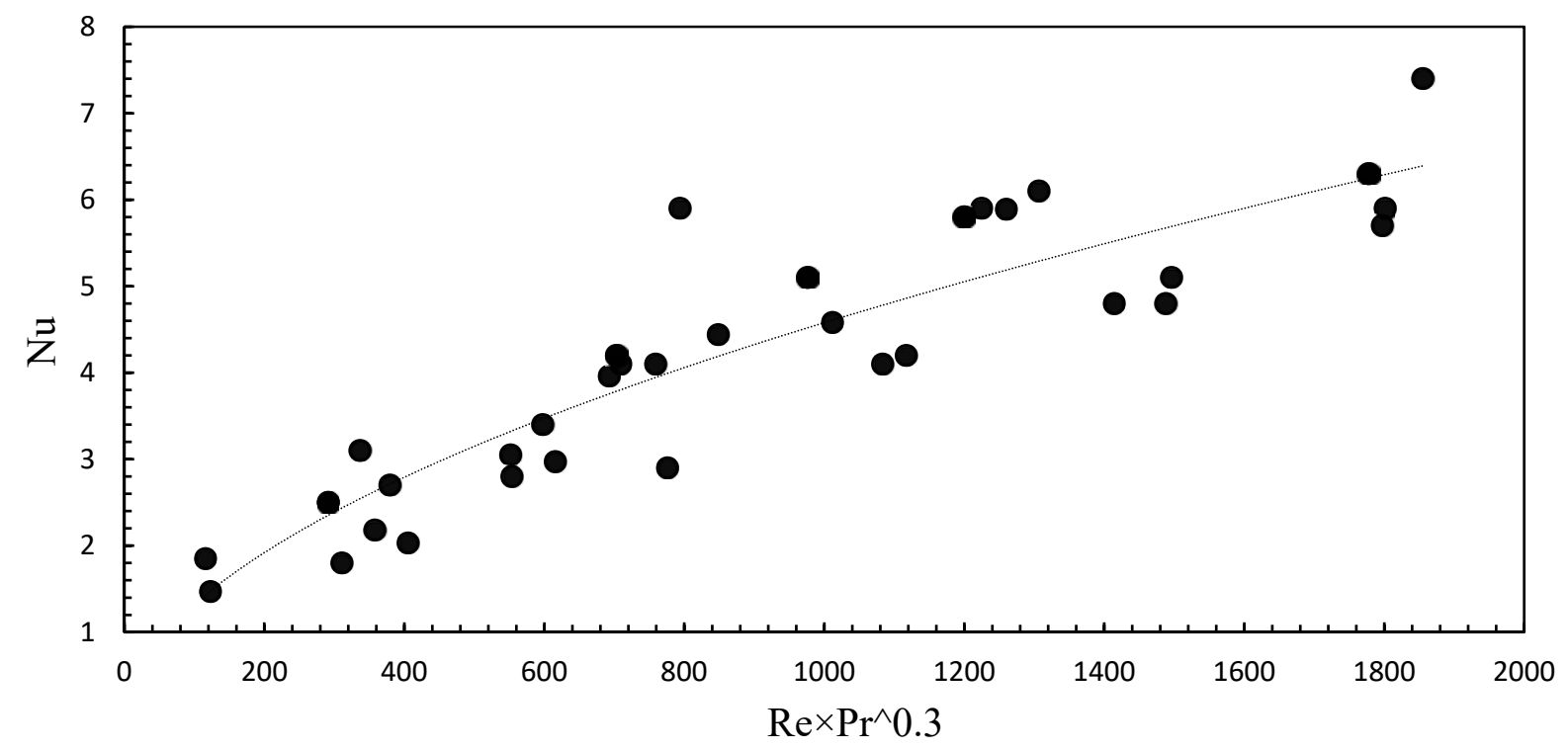

Figure 21. Effect of Reynolds and Prandtl numbers on Nusselt number (water side) at $40^{\circ} \mathrm{C}$, $50^{\circ} \mathrm{C}$ and $70^{\circ} \mathrm{C}$ of water inlet temperature, water flow rate (1 to $6 \mathrm{gpm}$ ) and air flow rate (682 to $394 \mathrm{cfm})$.

\subsection{Effect of Reynolds number and Prandtl number on Nusselt number for air side at same temperature}

Figure 22 depicts the effect of air flow rate on air side Nusselt Number at inlet temperature of water in the range of $68^{\circ} \mathrm{C}$ to $75^{\circ} \mathrm{C}$, at different water flow rates from 2 to $5 \mathrm{gpm}$. The air flow rate is varied from 682 to $394 \mathrm{cfm}$ and higher Nusselt number is observed for higher air flow rate. This is also due to the increased Reynolds number accompanied by increase in heat transfer rate and heat transfer coefficient for the air side. An empirical correlation is developed for the air side Nusselt number in terms of Reynolds and Prandtl number, similar to the one developed for water side. The correlation developed is valid for air in the laminar flow range of $500 \leq \mathrm{Rea}_{\mathrm{ea}} \leq 900$, when water's inlet temperature is in the range of $70^{\circ} \mathrm{C}$. It is derived using regression analysis in spreadsheet and presented below,

$$
N_{u a}=0.041 \times R_{e a}^{0.89} \times P_{r a}^{0.3} \text { and } R^{2}=0.60
$$




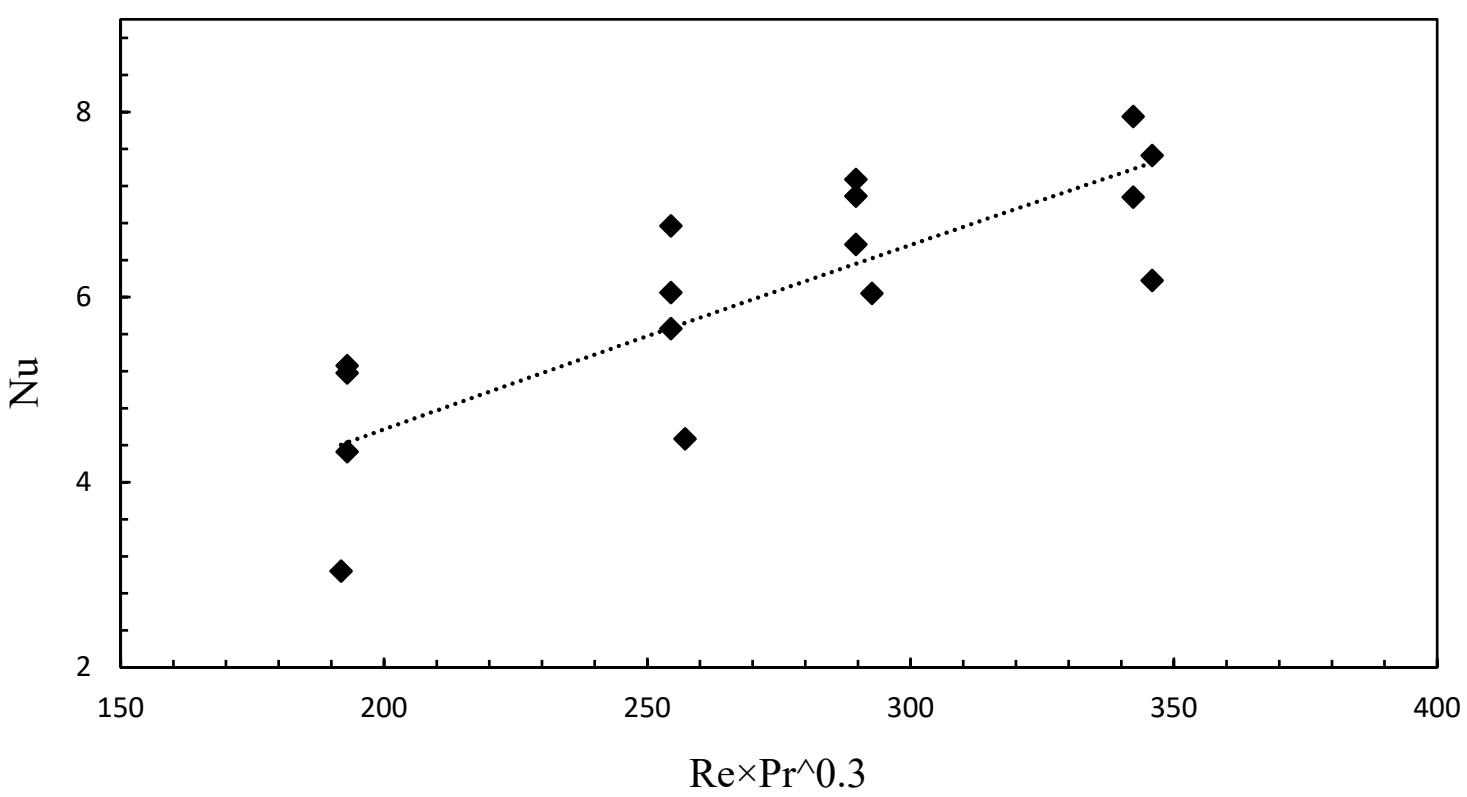

Figure 22. Effect of the Reynolds and Prandtl numbers on Nusselt number (air side) at inlet water temperature of $70^{\circ} \mathrm{C}$.

\subsection{Laminar flow correlations for water}

A variety of correlations are in use for predicting heat transfer rates in laminar flow at water side. As, heat is transferred efficiently in the thermal entrance region of laminar flow, Sieder and Tate developed a correlation for the Nusselt number for laminar flow heat transfer[23].

$$
N u=1.86\left(R_{e} P_{r}\right)^{0.3}\left(\frac{D}{T_{l}}\right)^{0.3}\left(\frac{\mu_{b}}{\mu_{w}}\right)^{0.14}
$$

When, uniform wall temperature boundary condition applies, $\mathrm{Nu}$ tends to 3.66 and for the constant heat flux boundary condition $\mathrm{Nu}$ tends to 4.36 . A heat transfer correlation for laminar flow was also provided by Mills shown in equation (29). This relation proved to be more accurate for longer tubes[23].

$$
N u=3.66+\frac{\frac{0.065 R_{e} P_{r} D}{T_{l}}}{1+0.04\left(\frac{R_{e} P_{r} D}{L}\right)^{0.6}}
$$

The experimental Nusselt number derived for different flow rates of water at three different temperatures is compared with the Nusselt number calculated from the Sieder-Tate and Mills correlations. The experimental value of Nusselt number is in good agreement with the value of 
Nusselt number calculated form Sieder-Tate correlation at $40^{\circ} \mathrm{C}$ and $50^{\circ} \mathrm{C}$, whereas the experimentally calculated Nusselt number at $70^{\circ} \mathrm{C}$ varies from Sieder-Tate correlation substantially. At low Reynolds number, the experimentally derived Nusselt Number in this research is lower than Nusselt number calculated using Sieder-Tate and Mills correlation, in comparison the Nusselt number at high Reynolds number calculated using Sieder-Tate and Mills correlation is found to be lower than experimentally derived Nusselt number. The difference occurs because Sieder-Tate correlation is derived for shorter tubes with circular cross section, whereas the heat exchanger used in this experiment has a rectangular cross section.

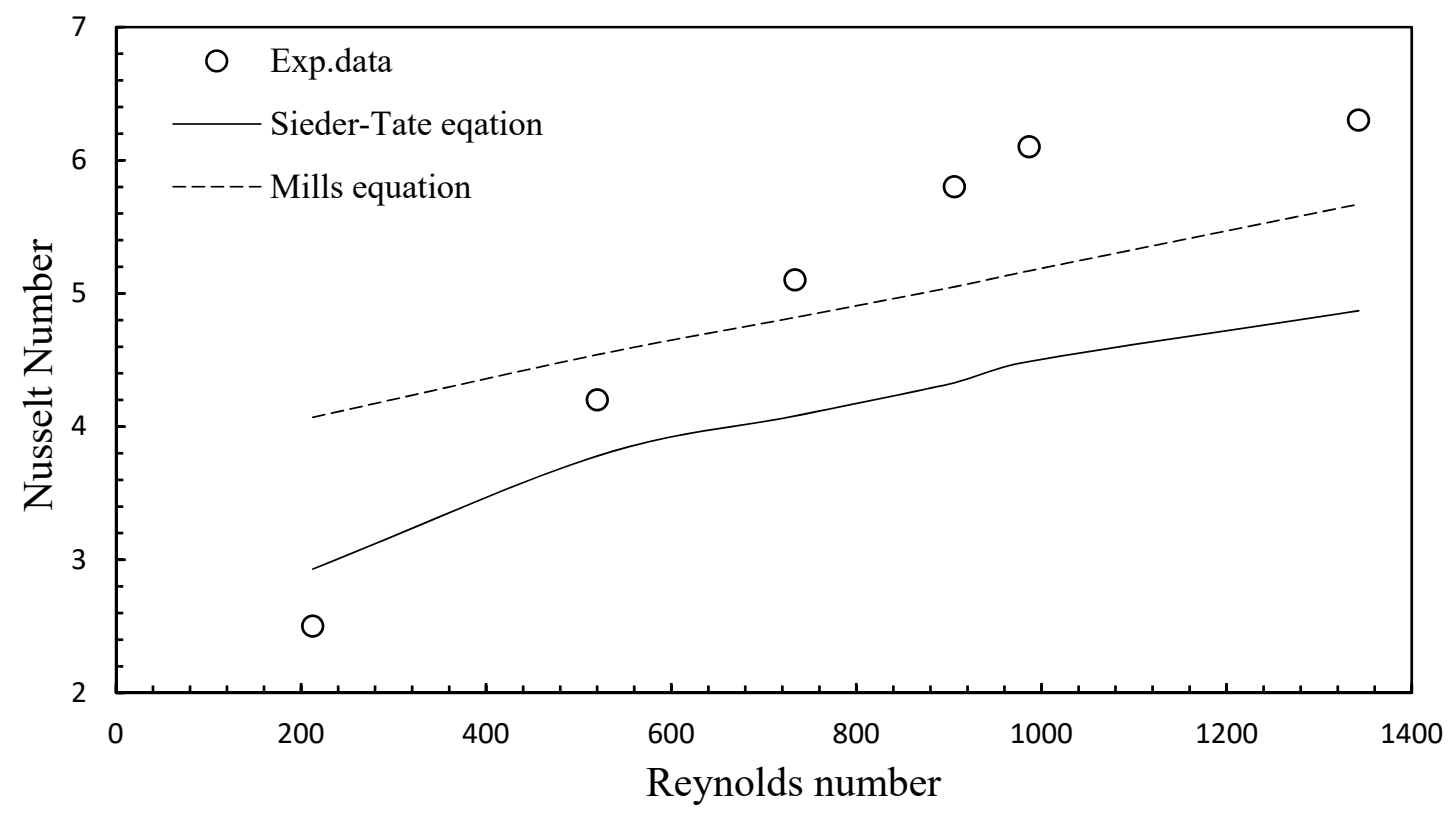

Figure 23. Effect of Reynolds Number on Nusselt Number (water side) at $70^{\circ} \mathrm{C}$. 


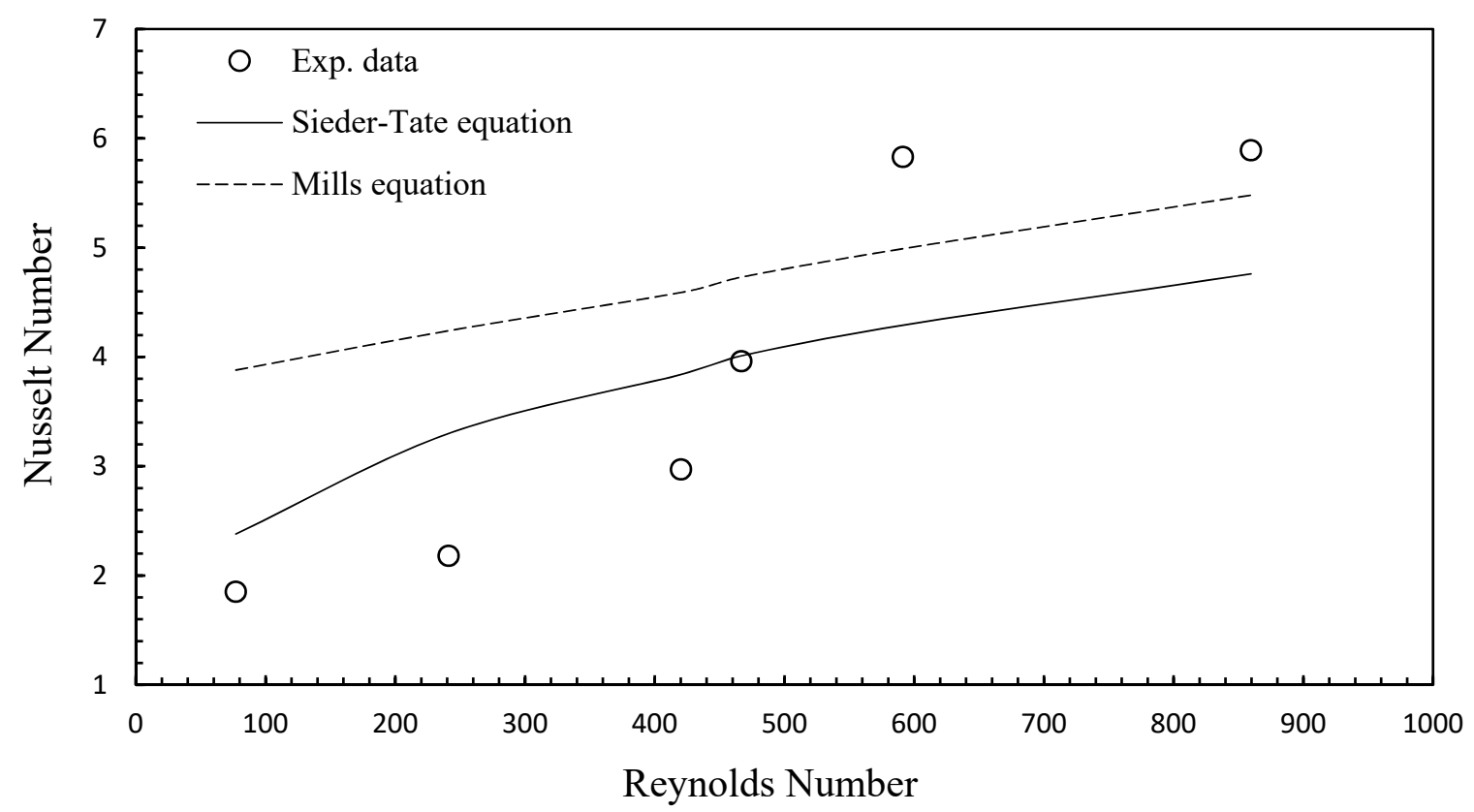

Figure 24. Effect of Reynolds Number on Nusselt Number (water side) at $50^{\circ} \mathrm{C}$.

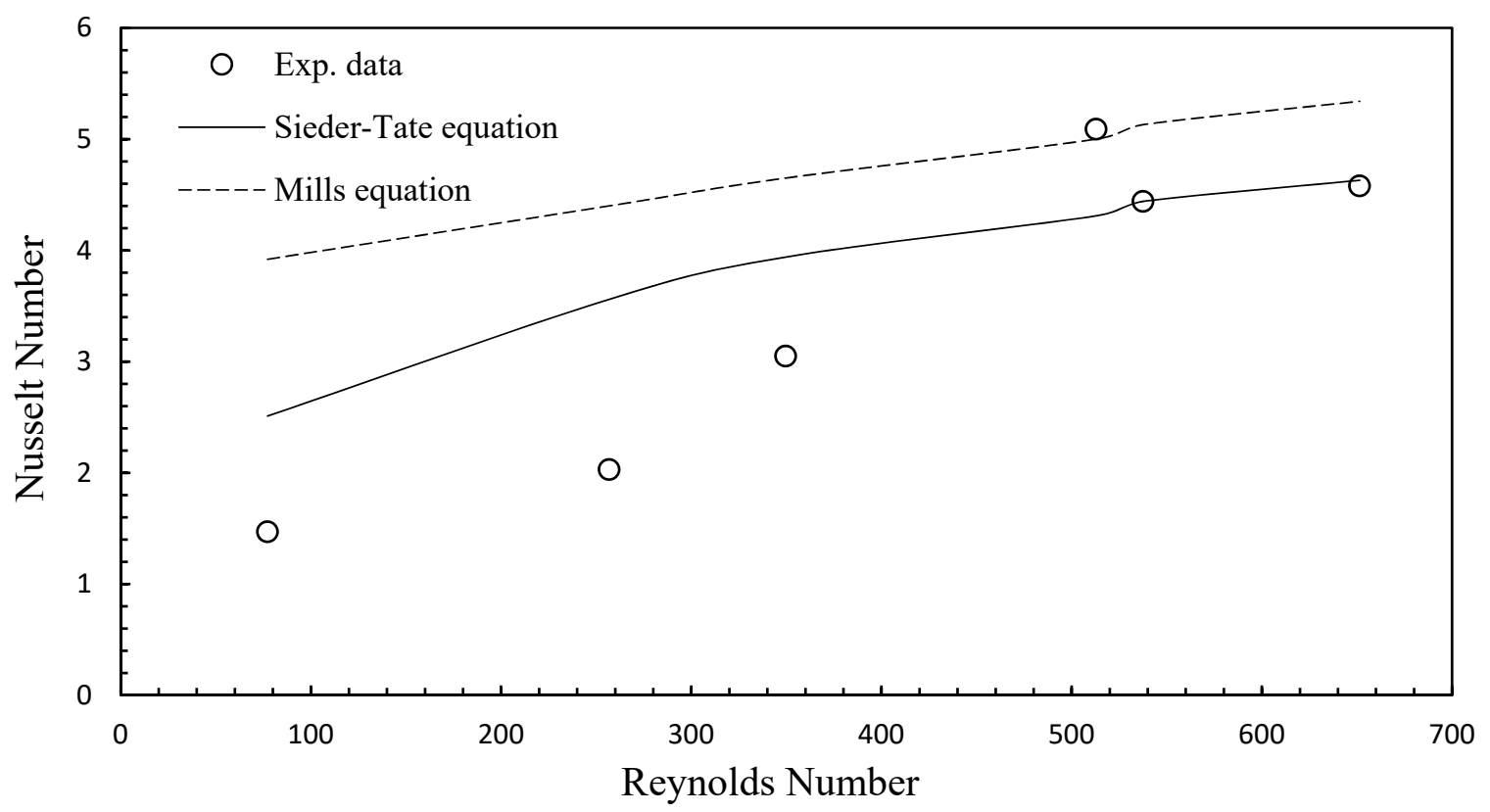

Figure 25. Effect of Reynolds Number on Nusselt Number at $40{ }^{\circ} \mathrm{C}$. 


\subsection{Comparison of design requirement and experimental results for heat exchanger}

The experimental results show that the given heat exchanger suffices the requirement of removing $2 \mathrm{~kW}$ at $40^{\circ} \mathrm{C}$, provided the flow rate on water is above $3 \mathrm{gpm}$ and air side flow rate is increased to $572.9 \mathrm{cfm}$. The comparison of design requirement and experimental investigation is tabulated in Table 17 for inlet temperature of $40^{\circ} \mathrm{C}$. Experimental value of overall heat transfer coefficient at $40^{\circ} \mathrm{C}$ is calculated as follows,

$$
\frac{1}{U A}=\frac{1}{h_{a} A_{s f}}+\frac{1}{h_{w} A_{s t}}
$$

Table 17. Comparison of design requirement and experimental result at $40{ }^{\circ} \mathrm{C}$.

\begin{tabular}{|l|l|l|}
\hline Data & Requirement & Experimental Results \\
\hline $\mathrm{Q}(\mathrm{kW})$ & 2 & 3.6 \\
\hline Mass flow rate of water $\mathrm{m}_{\mathrm{w}}(\mathrm{kg} / \mathrm{sec})$ & 0.24 & 0.25 \\
\hline Air flow rate $(\mathrm{cfm})$ & 500 & 572.9 \\
\hline Area $\left(m^{2}\right)$ & $8.1 \sim 16.3$ & 7.9 \\
\hline $\mathrm{U}^{*} \mathrm{~A}\left(\mathrm{~W} /{ }^{\circ} \mathrm{C}\right)$ & 406.8 & 396.6 \\
\hline
\end{tabular}




\section{Chapter 6 Conclusion and Future Work}

\subsection{Conclusion}

After detailed study on the liquid cooling system of the Free-piston stirling engine, a low cost and low power consumption liquid cooling system/heat rejection system is developed. The pressure loss and heat transfer of a liquid cooling system were thoroughly assessed before procuring a heat exchanger (radiator) and pump. A portable experimental test rig was designed in Solidworks and fabricated. Experimental investigation was performed on the heat exchanger using water as a coolant at $40^{\circ} \mathrm{C}, 50^{\circ} \mathrm{C}$ and $70^{\circ} \mathrm{C}$ of the inlet water temperature. For temperature measurement, two thermocouples were installed in the hose at the inlet and outlet of the heat exchanger and one thermocouple was installed at the fan's vent to measure the exit air temperature. Additionally, an infrared thermometer was used to measure the surface temperature at different points on the radiator. Mass flow rate of water was calculated by the bucket method. Air flow rate is measured by Thermo-anemometer.

The experimental data was processed to calculate the heat transfer rate, heat transfer coefficient, Reynolds number and Nusselt Number for both air and water side. The experimental result shows, higher heat transfer rate and heat transfer coefficient at $70^{\circ} \mathrm{C}$ than $40^{\circ} \mathrm{C}$ and $50^{\circ} \mathrm{C}$. It is because the entering temperature difference at $70^{\circ} \mathrm{C}$ is higher than $40^{\circ} \mathrm{C}$ and $50^{\circ} \mathrm{C}$, as temperature difference between air and water is higher.

The effect of Reynolds number and Prandtl number on Nusselt number was investigated on air as well as on water side. It was found that, the increase in Nusselt number is due to the increase in Reynolds number accompanied by increase in heat transfer rate. The empirical equation derived for Nusselt Number as a function of Reynolds and Prandtl Number for water side is in the form

$$
N_{u}=0.11 \times R_{e}^{0.54} \times P_{r}^{0.3}
$$

The derived correlation is valid for water at inlet temperature of $40^{\circ} \mathrm{C}, 50^{\circ} \mathrm{C}$ and $70^{\circ} \mathrm{C}$ for water flow rate in the range of 1 to $6 \mathrm{gpm}$ at air flow rate from (682 to $394 \mathrm{cfm}$ ). Nusselt number calculated from the experimental data at different temperature is consistent with the empirical equation reported by Sieder-Tate and Mills. The heat dissipation rate calculated from the experimental data at $40^{\circ} \mathrm{C}$ at $4.01 \mathrm{gpm}$ of water flow rate and $572.9 \mathrm{cfm}$ of air flow rate is found to be higher than the required heat dissipation rate of $2 \mathrm{~kW}$. Hence, the experimentally investigated heat exchanger suffices the requirement of the Stirling engine. 
Thus, it is concluded that the developed cooling system would work very well for a $1 \mathrm{~kW}$ Stirling engine. To further corroborate the conclusion, an experimental investigation on the pump should be conducted to validate the pressure losses which were theoretically calculated.

\subsection{Future Work}

Heat exchanger can be further experimentally investigated for the variety of coolants such as mixture of water/ethylene glycol and water/propylene glycol in 50:50 ratio. These mixtures as coolants work excellent at atmospheric conditions lower than $0^{\circ} \mathrm{C}$. In order to investigate the pressure drop in the heat exchanger, two differential pressure transducers should be installed, one at the inlet and another one at the exit of the heat exchanger.

As the test rig has the capability to experimentally investigate the entire cooling system, multiple test runs using the centrifugal pump should be carried out to validate the theoretical calculation of pressure loss. Additionally, the experimental test rig can be modified by installing a digital mass flow meter and a control valve to directly measure the mass flow rate of water. 


\section{References}

[1] S. Qiu, "Advanced Stirling Power Generation System for Combined Heat and Power," Arpa-E-Gensets, 2015.

[2] J. Majeski, “Stirling Engine Assessment," EPRI, Energy Int. Inc. 127 Bellevue W. SE Suite 200 Bellevue, WA 98004, vol. 1, no. 3, pp. 1-170, 2006.

[3] D. Beale, "Lean and Data Driven," Ohio University, 2016.

[4] N. Persaud, "Design and Optimzation of a Formula SAE Cooling," Thesis, Department of Mechanical and Industrial Engineering, University of Toronto, March 2007.

[5] I. Urieli, "Stirling Cycle Machine Analysis," Web Resource, Russ College of Engineering and Technology, Mechanical Engineering Department, Ohio University, 2018.

[6] D. Thombare, "Stirling Engine Micro-CHP System," no. January 2008, 2014.

[7] I. Urieli, “The Sunpower EG-1000 Stirling Engine/Generator,” Sunpower, 2014.

[8] S. Qiu, Y. Gao, G. Rinker, K. Yanaga, "Development of an Advanced Free-Piston Stirling Engine for Micro Combined Heating and Power Application,” Appl. Energy, vol. 235. 987-1000, 2018.

[9] L. Solomon \& S. Qiu, "Computational Analysis of External Heat Transfer for a Tubular Stirling Convertor,” Appl. Therm. Eng., vol. 137, 134-141, 2018.

[10] S. Qiu and A. Peterson, "STC Stirling Power System Development," 1st Int. Energy Convers. Eng. Conf., pp. 1-7, 2003.

[11] A. Sowale and A. Kolios, "Thermodynamic Performance of Heat Exchangers in a Free Piston Stirling Engine," Energies, vol. 11, no. 3, p. 505, 2018.

[12] J. P. Yadav and B. R. Singh, "Study on Performance Evaluation of Automotive Radiator," Samriddhi A J. Phys. Sci. Eng. Technol., vol. 2, no. 2, 2015.

[13] M. Gollin. and D. Bjork, "Comparative Performance of Ethylene Glycol/Water and Propylene Glycol/Water Coolants in Automobile Radiators," Soc. Automot. Eng., vol. 115-124, 1996. 
[14] J. Chen, D. Wang, and L. Zheng, "Experimental Study of Operating Performance of a Tube-and-Fin Radiator for Vehicles," Proceedings of The Institution of Mechanical Engineers Part D-Journal of Automobile Engineering., vol. 215, no. 8, pp. 911-918, 2001.

[15] C. Oliet, A. Oliva, J. Castro, and C. D. Pérez-Segarra, "Parametric Studies on Automotive Radiators," Appl. Therm. Eng., vol. 27, no. 11-12, pp. 2033-2043, 2007.

[16] S. Nirnjalkumar and P. Gopal, "Design and Development of an Automobile Radiator Test Rig and Development of Heat Transfer Correlations for," no. 6, pp. 297-299, 2015.

[17] M. Carl, D. Guy, B. Leyendecker, A. Miller, and X. Fan, "The Theoretical and Experimental Investigation of the Heat Transfer Process of an Automobile Radiator" 2012 ASEE Gulf Southwest Annual Conference April 4-6, El Paso , Texas, vol. 1, no. 128, pp. $1-12,2012$.

[18] H. Pablo, "How to Design a Liquid Cooling System," Aavid Thermacore, 2016.

[19] F. P. Incropera, D. P. DeWitt, T. L. Bergman, and A. S. Lavine, Fundamentals of Heat and Mass Transfer. John Wiley and Sons, Inc., 2007.

[20] B. R. Munson, D. F. Young, T. H. Okiishi and W. W. Huebsch, Fundamentals of Fluid Mechanics. John Wiley and Sons, Inc., 2009.

[21] A. Pandey, "Performance Analysis of a Compact Heat Exchanger", Department of Mechanical Engineering National Institute of Technology, Mech. Eng., 2011.

[22] A. Gulhane, "Experimental Investigation of Convective Heat Transfer for Radiator by Using Nanofluid,” no. January 2015.

[23] S. Shankar, "Heat Transfer in Flow through Conduits", Department of Chemical and Biomolecular Engineering, Clarkson University. 


\section{Appendix}

First part of the appendix presents the theoretical pressure loss calculations at various flow rates for different hose diameter.

Table 18. Pressure drop using water as a coolant at $3 \mathrm{gpm}$.

\begin{tabular}{|c|c|c|c|c|}
\hline \multirow{2}{*}{ Calculated Data } & \multicolumn{4}{|c|}{ Hose Diameter, m } \\
\hline & 0.012 & 0.015 & 0.019 & 0.025 \\
\hline Volumetric flow rate (gpm) & 3 & 3 & 3 & 3 \\
\hline Major head loss (meter) & 0.5 & 0.1 & 0.06 & 0.016 \\
\hline Minor head loss (meter) & 1.7 & 0.7 & 0.3 & 0.094 \\
\hline Total pressure drop (pascal) & 22126.8 & 8740.6 & 3284.8 & 1060.9 \\
\hline
\end{tabular}

Table 19. Pressure drop using water as a coolant at $4 \mathrm{gpm}$.

\begin{tabular}{|c|c|c|c|c|}
\hline \multirow{2}{*}{ Calculated Data } & \multicolumn{4}{|c|}{ Hose Diameter, m } \\
\hline & 0.012 & 0.015 & 0.019 & 0.025 \\
\hline Volumetric flow rate (gpm) & 4 & 4 & 4 & 4 \\
\hline Major head loss (meter) & 0.8 & 0.3 & 0.09 & 0.02 \\
\hline Minor head loss (meter) & 3.1 & 1.3 & 0.5 & 0.1 \\
\hline Total pressure drop (pascal) & 38555.8 & 15253.5 & 5740.9 & 1856.9 \\
\hline
\end{tabular}

Table 20. Pressure drop using water as a coolant at $5 \mathrm{gpm}$.

\begin{tabular}{|l|l|l|l|l|}
\hline \multirow{2}{*}{ Calculated Data } & \multicolumn{4}{c|}{ Hose Diameter, m } \\
\cline { 2 - 5 } & & & & \\
& & & & \\
& & & & \\
\multirow{2}{*}{ Volumetric flow rate (gpm) } & 5 & 0.015 & 0.019 & 0.025 \\
\hline Major head loss (meter) & 1.3 & 0.4 & 0.1 & 0.04 \\
\hline Minor head loss (meter) & 4.9 & 2.01 & 0.8 & 0.3 \\
\hline Total pressure drop (pascal) & 59795.5 & 23683.4 & 8923.5 & 2889.7 \\
\hline
\end{tabular}


Table 21. Pressure drop using water as a coolant at $6 \mathrm{gpm}$.

\begin{tabular}{|l|l|l|l|l|}
\hline \multirow{2}{*}{ Calculated Data } & \multicolumn{4}{c|}{ Hose Diameter, m } \\
\cline { 2 - 5 } & \multirow{2}{*}{0.012} & 0.015 & 0.019 & 0.025 \\
\hline Volumetric flow rate (gpm) & 6 & 6 & 6 & 6 \\
\hline Major head loss (meter) & 1.8 & 0.6 & 0.2 & 0.05 \\
\hline Minor head loss (meter) & 7.09 & 2.9 & 1.1 & 0.4 \\
\hline Total pressure drop (pascal) & 85583.7 & 33928 & 12794.6 & 4147 \\
\hline
\end{tabular}

Table 22. Pressure drop using water as a coolant at $7 \mathrm{gpm}$.

\begin{tabular}{|l|l|l|l|l|}
\hline \multirow{2}{*}{\multicolumn{1}{c|}{ Calculated Data }} & \multicolumn{4}{c|}{ Hose Diameter, m } \\
\cline { 2 - 6 } & & & & \\
& 0.012 & 0.015 & 0.019 & 0.025 \\
\hline Volumetric flow rate (gpm) & 7 & 7 & 7 & 7 \\
\hline Major head loss (meter) & 2.3 & 0.8 & 0.3 & 0.07 \\
\hline Minor head loss (meter) & 9.5 & 3.9 & 1.5 & 0.5 \\
\hline Total pressure drop (pascal) & 114848.9 & 45562.2 & 17193.7 & 5576.8 \\
\hline
\end{tabular}


Second part of appendix presents the raw data measurement and data processed at $70{ }^{\circ} \mathrm{C}, 50^{\circ} \mathrm{C}$ and $40{ }^{\circ} \mathrm{C}$.

Table 23. Effect of coolant's (water) flow rate on heat transfer rate (water side) and other parameters at constant air flow rate at $682 \mathrm{cfm}$ at $70^{\circ} \mathrm{C}$.

\begin{tabular}{|c|c|c|c|c|c|c|c|c|c|c|c|}
\hline $\begin{array}{c}\mathrm{V}_{w} \\
(\mathrm{gpm})\end{array}$ & $\begin{array}{c}\mathrm{m}_{\mathrm{w}} \\
(\mathrm{kg} / \mathrm{sec})\end{array}$ & $\begin{array}{c}\mathrm{T}_{\mathrm{in}, \mathrm{w}} \\
\left({ }^{\circ} \mathrm{C}\right)\end{array}$ & $\begin{array}{c}\mathrm{T}_{\text {out, } \mathrm{w}} \\
\left({ }^{\circ} \mathrm{C}\right)\end{array}$ & $\begin{array}{c}\mathrm{T}_{\text {in,a }} \\
\left({ }^{\circ} \mathrm{C}\right)\end{array}$ & $\begin{array}{c}\mathrm{T}_{\text {out,a }} \\
\left({ }^{\circ} \mathrm{C}\right)\end{array}$ & $\begin{array}{c}\mathrm{T}_{\mathrm{w}} \\
\left({ }^{\circ} \mathrm{C}\right)\end{array}$ & $\begin{array}{c}\mathrm{Q}_{\mathrm{w}} \\
(\mathrm{W})\end{array}$ & $\begin{array}{c}\mathrm{h}_{\mathrm{w}}(W / \\
\left.m^{2} \mathrm{C}\right)\end{array}$ & $\mathrm{Re}_{\mathrm{w}}$ & $\mathrm{Nu}_{\mathrm{w}}$ & $\mathrm{Pr}_{\mathrm{w}}$ \\
\hline 1.21 & 0.075 & 69.3 & 57.9 & 21.7 & 43.2 & 58.6 & 3584.7 & 742.2 & 245.7 & 3.1 & 2.8 \\
\hline 2.50 & 0.155 & 67.4 & 60.5 & 21.7 & 49.8 & 59.2 & 4478.0 & 975.9 & 522.1 & 4.1 & 2.7 \\
\hline 2.85 & 0.177 & 66.8 & 57.5 & 21.7 & 50.6 & 57.1 & 6890.6 & 1412.5 & 579.1 & 5.9 & 2.8 \\
\hline 4.13 & 0.256 & 72.3 & 64.5 & 21.7 & 58.2 & 62.3 & 8366.6 & 1419.8 & 918.7 & 5.9 & 2.6 \\
\hline 5.01 & 0.311 & 71.9 & 65.3 & 21.7 & 59.2 & 60.9 & 8598.3 & 1156.0 & 1116.0 & 4.8 & 2.6 \\
\hline 5.93 & 0.368 & 74.2 & 68.1 & 21.7 & 58.7 & 64.2 & 9408.0 & 1401.3 & 1363.5 & 5.9 & 2.5 \\
\hline
\end{tabular}


Table 24. Effect of coolant's (water) flow rate on heat transfer rate (water side) and other parameters at constant air flow rate at $518.11 \mathrm{cfm}$ at $70^{\circ} \mathrm{C}$.

\begin{tabular}{|c|c|c|c|c|c|c|c|c|c|c|c|}
\hline $\begin{array}{c}\mathrm{V}_{w} \\
(\mathrm{gpm})\end{array}$ & $\begin{array}{c}\mathrm{m}_{\mathrm{w}} \\
(\mathrm{kg} / \mathrm{sec})\end{array}$ & $\begin{array}{c}\mathrm{T}_{\mathrm{in}, \mathrm{w}} \\
\left({ }^{\circ} \mathrm{C}\right)\end{array}$ & $\begin{array}{c}\mathrm{T}_{\text {out, } \mathrm{w}} \\
\left({ }^{\circ} \mathrm{C}\right)\end{array}$ & $\begin{array}{c}\mathrm{T}_{\text {in,a }} \\
\left({ }^{\circ} \mathrm{C}\right)\end{array}$ & $\begin{array}{c}\mathrm{T}_{\text {out,a }} \\
\left({ }^{\circ} \mathrm{C}\right)\end{array}$ & $\begin{array}{c}\mathrm{T}_{\mathrm{w}} \\
\left({ }^{\circ} \mathrm{C}\right)\end{array}$ & $\begin{array}{c}\mathrm{Q}_{\mathrm{w}} \\
(\mathrm{W})\end{array}$ & $\begin{array}{c}\mathrm{h}_{\mathrm{w}}(W / \\
\left.m^{2} \mathrm{C}\right)\end{array}$ & $\mathrm{Re}_{\mathrm{w}}$ & $\mathrm{Nu}_{\mathrm{w}}$ & $\mathrm{Pr}_{\mathrm{w}}$ \\
\hline 1.33 & 0.082 & 69.5 & 58.3 & 21.7 & 44.1 & 57.8 & 3845.3 & 652.6 & 280.7 & 2.7 & 2.7 \\
\hline 2.03 & 0.126 & 70.8 & 62.3 & 21.7 & 51.7 & 60.9 & 4485.9 & 821.9 & 446.8 & 3.4 & 2.6 \\
\hline 2.62 & 0.162 & 71.5 & 64.8 & 21.7 & 53.5 & 61.4 & 4546.7 & 697.3 & 582.8 & 2.9 & 2.6 \\
\hline 3.72 & 0.230 & 71.9 & 65.3 & 21.7 & 58.5 & 62.1 & 6358.9 & 1012.7 & 843.8 & 4.2 & 2.5 \\
\hline 4.97 & 0.308 & 71.7 & 66.2 & 21.7 & 59.5 & 62.9 & 7097.9 & 1214.5 & 1129.9 & 5.1 & 2.5 \\
\hline 5.97 & 0.370 & 71.9 & 66.7 & 21.7 & 62.1 & 63.2 & 8061.6 & 1368.1 & 1357.3 & 5.7 & 2.5 \\
\hline
\end{tabular}

Table 25. Effect of coolant's (water) flow rate on heat transfer rate (water side) and other parameters at constant air flow rate at $394.47 \mathrm{cfm}$ at $70^{\circ} \mathrm{C}$

\begin{tabular}{|c|c|c|c|c|c|c|c|c|c|c|c|}
\hline $\begin{array}{c}\mathrm{V}_{w} \\
(\mathrm{gpm})\end{array}$ & $\begin{array}{c}\mathrm{m}_{\mathrm{w}} \\
(\mathrm{kg} / \mathrm{sec})\end{array}$ & $\begin{array}{c}\mathrm{T}_{\text {in,w }} \\
\left({ }^{\circ} \mathrm{C}\right)\end{array}$ & $\begin{array}{c}\mathrm{T}_{\text {out, }} \\
\left({ }^{\circ} \mathrm{C}\right)\end{array}$ & $\begin{array}{c}\mathrm{T}_{\mathrm{in}, \mathrm{a}} \\
\left({ }^{\circ} \mathrm{C}\right)\end{array}$ & $\begin{array}{c}\mathrm{T}_{\text {out,a }} \\
\left({ }^{\circ} \mathrm{C}\right)\end{array}$ & $\begin{array}{c}\mathrm{T}_{\mathrm{w}} \\
\left({ }^{\circ} \mathrm{C}\right)\end{array}$ & $\begin{array}{c}\mathrm{Q}_{\mathrm{w}} \\
(\mathrm{W})\end{array}$ & $\begin{array}{c}\mathrm{h}_{\mathrm{w}}(W / \\
\left.m^{2}{ }^{\circ} \mathrm{C}\right)\end{array}$ & $\mathrm{Re}_{\mathrm{w}}$ & $\mathrm{Nu}_{\mathrm{w}}$ & $\mathrm{Pr}_{\mathrm{w}}$ \\
\hline 1.12 & 0.069 & 67 & 59.2 & 21.7 & 43.1 & 57.6 & 2252.9 & 424.0 & 227.3 & 1.8 & 2.8 \\
\hline 1.84 & 0.114 & 68.7 & 61.8 & 21.7 & 49.7 & 60.2 & 3295.9 & 675.6 & 418.2 & 2.8 & 2.5 \\
\hline 2.58 & 0.160 & 71.2 & 64.2 & 21.7 & 59.1 & 62.8 & 4691.7 & 991.2 & 567.3 & 4.1 & 2.6 \\
\hline 3.59 & 0.223 & 72.1 & 65.8 & 21.7 & 61.2 & 62.7 & 5886.5 & 975.0 & 818.1 & 4.1 & 2.5 \\
\hline 4.66 & 0.289 & 72.6 & 67.2 & 21.7 & 60.7 & 64 & 6538.9 & 1147.3 & 1070.8 & 4.8 & 2.5 \\
\hline 6.10 & 0.379 & 72.4 & 67.2 & 21.7 & 62.1 & 65 & 8257.7 & 1780.9 & 1404.3 & 7.4 & 2.5 \\
\hline
\end{tabular}


Table 26. Effect of coolant's (water) flow rate on heat transfer rate (water side) and other parameters at constant air flow rate $572.9(\mathrm{cfm})$ at $40^{\circ} \mathrm{C}$.

\begin{tabular}{|c|c|c|c|c|c|c|c|c|c|c|c|}
\hline $\begin{array}{c}\mathrm{V}_{w} \\
(\mathrm{gpm})\end{array}$ & $\begin{array}{c}\mathrm{m}_{\mathrm{w}} \\
(\mathrm{kg} / \mathrm{sec})\end{array}$ & $\begin{array}{c}\mathrm{T}_{\text {in, }} \\
\left({ }^{\circ} \mathrm{C}\right)\end{array}$ & $\begin{array}{c}\mathrm{T}_{\text {out }, \mathrm{w}} \\
\left({ }^{\circ} \mathrm{C}\right)\end{array}$ & $\begin{array}{c}\mathrm{T}_{\text {in, }} \\
\left({ }^{\circ} \mathrm{C}\right)\end{array}$ & $\begin{array}{c}\mathrm{T}_{\text {out, }} \\
\left({ }^{\circ} \mathrm{C}\right)\end{array}$ & $\begin{array}{c}\mathrm{T}_{\mathrm{w}} \\
\left({ }^{\circ} \mathrm{C}\right)\end{array}$ & $\begin{array}{c}\mathrm{Q}_{\mathrm{w}} \\
(\mathrm{W})\end{array}$ & $\begin{array}{c}\mathrm{h}_{\mathrm{w}}(W / \\
\left.m^{2}{ }^{\circ} \mathrm{C}\right)\end{array}$ & $\mathrm{Re}_{\mathrm{w}}$ & $\mathrm{Nu}_{\mathrm{w}}$ & $\mathrm{Pr}_{\mathrm{w}}$ \\
\hline 0.61 & 0.037 & 39.4 & 33.7 & 21.7 & 27.9 & 33.8 & 881.2 & 331.4 & 77.2 & 1.5 & 4.8 \\
\hline 1.93 & 0.119 & 41.8 & 37.6 & 21.7 & 30.6 & 35.0 & 2088.4 & 459.6 & 256.9 & 2.0 & 4.6 \\
\hline 2.62 & 0.162 & 39.3 & 36.0 & 21.7 & 33.1 & 34.3 & 2233.8 & 689.7 & 349.7 & 3.0 & 4.6 \\
\hline 4.65 & 0.226 & 41.3 & 37.5 & 21.7 & 34.5 & 36.2 & 3588.5 & 1159.9 & 512.9 & 5.1 & 4.3 \\
\hline 4.01 & 0.249 & 40.5 & 37.0 & 21.7 & 35.7 & 35.0 & 3641.6 & 1004.4 & 537.6 & 4.4 & 4.6 \\
\hline 4.63 & 0.287 & 40.2 & 37.6 & 21.7 & 35.0 & 35.8 & 3118.0 & 1040.3 & 651.4 & 4.6 & 4.3 \\
\hline
\end{tabular}

Table 27. Effect of coolant's (water) flow rate on heat transfer rate (water side) and other parameters at constant air flow rate $572.9(\mathrm{cfm})$ at $50^{\circ} \mathrm{C}$.

\begin{tabular}{|c|c|c|c|c|c|c|c|c|c|c|c|}
\hline $\begin{array}{c}\mathrm{V}_{w} \\
(\mathrm{gpm})\end{array}$ & $\begin{array}{c}\mathrm{m}_{\mathrm{w}} \\
(\mathrm{kg} / \mathrm{sec})\end{array}$ & $\begin{array}{c}\mathrm{T}_{\text {in,w }} \\
\left({ }^{\circ} \mathrm{C}\right)\end{array}$ & $\begin{array}{c}\mathrm{T}_{\text {out } \mathrm{w}} \\
\left({ }^{\circ} \mathrm{C}\right)\end{array}$ & $\begin{array}{c}\mathrm{T}_{\text {in,a }} \\
\left({ }^{\circ} \mathrm{C}\right)\end{array}$ & $\begin{array}{c}\mathrm{T}_{\text {out }, \mathrm{a}} \\
\left({ }^{\circ} \mathrm{C}\right)\end{array}$ & $\begin{array}{c}\mathrm{T}_{\mathrm{w}} \\
\left({ }^{\circ} \mathrm{C}\right)\end{array}$ & $\begin{array}{c}\mathrm{Q}_{\mathrm{w}} \\
(\mathrm{W})\end{array}$ & $\begin{array}{c}\mathrm{h}_{\mathrm{w}}(W / \\
\left.m^{2}{ }^{\circ} \mathrm{C}\right)\end{array}$ & $\mathrm{Re}_{\mathrm{w}}$ & $\mathrm{Nu}_{\mathrm{w}}$ & $\mathrm{Pr}_{\mathrm{w}}$ \\
\hline 0.50 & 0.031 & 50.5 & 39.1 & 21.7 & 26.4 & 41.2 & 1477.4 & 424.4 & 77.1 & 1.8 & 3.9 \\
\hline 1.46 & 0.093 & 50.9 & 44.2 & 21.7 & 32.5 & 42.2 & 2604.9 & 503.6 & 241.2 & 2.2 & 3.7 \\
\hline 2.52 & 0.156 & 51.3 & 45.2 & 21.7 & 38.2 & 42.3 & 3978.2 & 691.5 & 420.4 & 3.0 & 3.6 \\
\hline 3.61 & 0.180 & 50.9 & 45.2 & 21.7 & 37.3 & 43.2 & 4289.2 & 914.7 & 466.8 & 4.0 & 3.7 \\
\hline 5.14 & 0.319 & 50.5 & 45.4 & 21.7 & 40.2 & 42.8 & 6801.3 & 1365.9 & 859.6 & 5.9 & 3.6 \\
\hline
\end{tabular}

